\title{
O PAPADO DE PIO IXE A DINAMIZAÇÃO TRANSCONTINENTAL DO ANTICLERICALISMO OITOCENTISTA: ECOS NO PARLAMENTO IMPERIAL BRASILEIRO'
}

\section{(D) Ivo Pereira da Silva ${ }^{2,3}$}

\section{RESUMO}

Este artigo aborda o anticlericalismo da segunda metade do século XIX em alguns Estados europeus e no Parlamento imperial brasileiro. O momento dinamizador da militância anticlerical foi durante e após o pontificado de Pio IX (1846-1878), período em que a Igreja Católica assumiu uma série de posições e posturas conservadoras frente a transformações políticas, sociais e culturais, colocando-se em rota de colisão com ideias tidas como modernizadoras à época. O ponto de referência, como critério para analisar os casos europeus, foram os discursos e debates ocorridos na Câmara dos Deputados e no Senado Imperial brasileiro. O objetivo da investigação consistiu em evidenciar como parlamentares das duas casas legislativas estavam em sintonia com os movimentos anticlericais na Europa, assim como com o exemplo norte-americano de separação entre Estado e Igreja. Os resultados da pesquisa, cuja principal contribuição foi apresentar a circularidade de ideias e de modelos de separabilidade entre Igreja e Estado, sugerem que a laicidade brasileira, implantada com o advento da República (1889), tem uma dupla fonte, tanto europeia como estadunidense.

\section{PATAVRAS-CHAVE}

Anticlericalismo - Papa Pio IX - Separação entre Igreja e Estado.

1 Texto vinculado ao projeto de Pesquisa "As matrizes da secularização e laicidade da República brasileira. Os debates sobre as relações entre o Estado e as Igrejas na Primeira Constituinte Republicana Brasileira (1878-1891)", desenvolvido no âmbito do Edital Prodoutor (PRO3724-2019), Propesp, UFPA.

2 Universidade Federal do Pará - Campus Cametá. Cametá - Pará - Brasil.

3 Professor Adjunto de História Moderna e Contemporânea da Faculdade de História da Amazônia Tocantina, Campus de Cametá, da Universidade Federal do Pará. E-mail: ivosilva@ufpa.br 


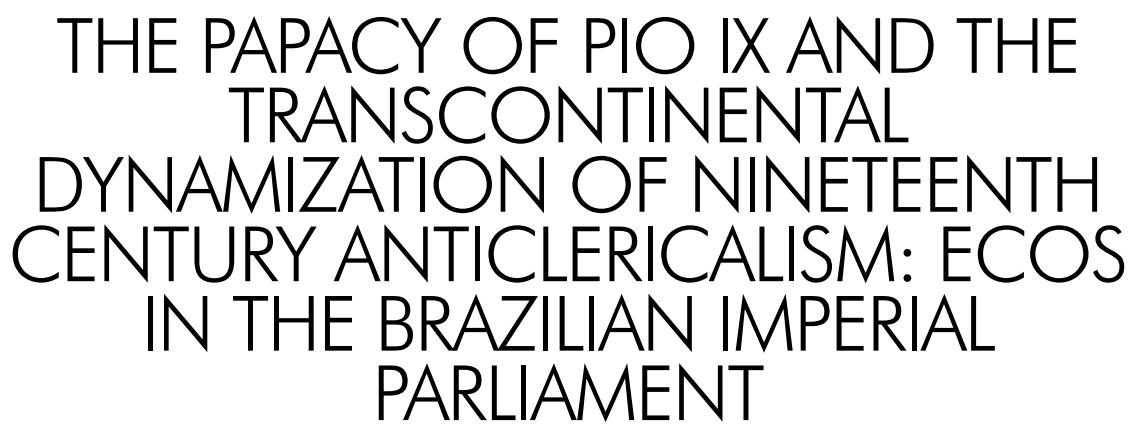

This article deals with the anticlericalism of the second half of the 19th century in some European States and in the Imperial Brazilian Parliament. The dynamic moment of anticlerical militancy was during and after the Pontificate of Pius IX (18461878), a period in which the Catholic Church assumed a series of conservative positions and postures in the face of political, social and cultural transformations that put it on a collision course with as modernized ideas of the time. The reference point, as a criterion for the analysis of European cases, were the speeches and debates that took place in the Chamber of Deputies and in the Imperial Brazilian Senate. The objective of the investigation was to show how the parliamentarians, from the two legislative houses, were in tune with the anticlerical movements in Europe, as well as in the North American example of selection between the State and the Church. The results of the research, the main contribution being the presentation of the circularity of ideas and models of separation between Church and State, suggested the Brazilian secularism, implanted with the advance of the Republic (1889), has a double source, both in Europe in the USA.

\section{KEYWORDS}

Anticlericalism - Pope Pius IX - Separation of Church and State. 


\section{Introdução}

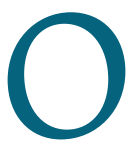

estudo das incidências do anticlericalismo durante a segunda metade do século XIX não deve ser feito sem a prévia compreensão de que o fenômeno possui elementos comuns aos países católicos da Europa e das Américas (sul e norte), merecendo destaque a influência do Iluminismo e da Revolução Francesa e o contraste entre os Estados nacionais em construção e a Igreja de Roma ${ }^{4}$. Em decorrência dos embates entre clericais e anticlericais, essa instituição foi vista, pelas forças reformistas e revolucionárias, como um dos sustentáculos do Antigo Regime e da ordem colonial, razão pela qual muitos dos "herdeiros da revolução não pensam poder preservar e consolidar as conquistas de 1789 sem desarmar a Igreja"' . Por isso, a construção dos processos de modernidade política $^{6}$ - isto é, liberdade de consciência e de expressão, laicidade do

4 Além da ampla bibliografia e das fontes, três obras coletivas suportam este artigo: AYER. Madrid: Asociación de Historia Contemporánea, v. 27, 1997. El anticlericalismo. Edição de Rafael Cruz Martínez; DI STEFANO, Roberto (org.). Pasiones anticlericales: uno recorrido iberoamericano. Bernal: Universidad Nacional de Quilmes, 2013; SOLIS, Yves; SAVARINO, Franco (org.). El anticlericalismo en Europa y América Latina: una visión transatlántica. Ciudad de México: Instituto Nacional de Antropología e Historia, 2011.

5 Durante o processo revolucionário, os jacobinos, sob a liderança de Maximilien Robespierre, iniciaram um projeto de descristianização que, segundo Michel Volvelle, é herdeiro de uma longa tradição adormecida de anticlericalismo popular que a revolução potencializou. Cf. VOLVELLE, Michel. A Revolução Francesa contra a Igreja: da razão ao ser supremo. Rio de Janeiro: Jorge Zahar, 1989.

$6 \mathrm{O}$ conceito e o recorte temporal da modernidade não é consensual. Em que pese esse fato, utilizase aqui a definição de modernidade para representar um período histórico que, pelo menos desde o século XVIII, indicia um processo de autonomia do homem em relação aos entraves que o impedem de "pensar por si só" - verdadeiro brado autonômico do homem em oposição às autoridades políticas e eclesiásticas do Antigo Regime, como bem evidenciou Immanuel Kant na adoção da expressão sapere aude ("Ouse saber!"). Nesse sentido, a modernidade é "filha" do Iluminismo e da Revolução Francesa. O sociólogo Peter Berger, na obra Os múltiplos altares da Modernidade, faz a seguinte pergunta: “Como a modernidade afeta a religião?”. O autor de O dossel sagrado escreve que os pensadores do Iluminismo combateram tenazmente a religião, que foi 
Estado, soberania nacional frente ao poder supranacional de Roma, responsabilidade do Estado em matéria de formação moral e cívica do indivíduo etc -, nos países de hegemonia católica, foi acompanhada pela emergência daquilo a que no século XIX se chamará, mesmo em suas expressões menos extremas, "questão religiosa", ou culture wars, como propõem Christopher Clark e Wolfram Kaiser ${ }^{8}$. Tudo isso nos autoriza a sustentar que os conflitos com a Igreja Católica envolvendo Estados nacionais da Europa e os da futuramente chamada América Latina ${ }^{9}$, não obstante a especificidade de cada processo,

"equiparada à superstição" e deveria ser "varrida pela luz brilhante da razão". Por conseguinte, uma das faces da modernidade é o seu profundo anticlericalismo. Não só a França, mas diversos Estados europeus e americanos compartilharam a dimensão antirreligiosa da modernidade, passando a defender uma visão de mundo laica, promovendo o livre uso da razão, o indiferentismo religioso, a autonomia das leis morais em relação à lei divina, a autonomia filosófica e da ética, liberdade de consciência, de opinião, religião e cultos, a defesa da separação dos Estados em relação às Igrejas etc. Toda essa realidade seria combatida pela Igreja Católica numa série de documentos papais desde o século XVIII: carta Quod aliquamtum (1791), encíclica Ubi primum (1824), encíclica Mirari vos (1832), com destaque para as encíclicas do Papa Pio IX, Noscitis et nobiscum (1849) e Quanta cura, seguida do Syllabus (1864). Portanto, para a Igreja Católica, a modernidade representaria a secularização, a laicidade e a autonomia do homem frente ao poder eclesiástico, e tudo isso seria materializado nas propostas de separação dos Estados em relação à Igreja. Cf. KANT, Immanuel. "Resposta à pergunta: o que é o Iluminismo". In: KANT, Immanuel. Da paz perpétua e outros opúsculos. Lisboa: Edições 70, 2009; CATROGA, Fernando. Entre deuses e césares. Secularização, Laicidade e Religião Civil. Uma perspectiva histórica. Coimbra: Almedina, 2006, pp. 286-287; BERGER, Peter. Os múltiplos altares da modernidade: rumo a um paradigma da religião numa época pluralista. Petrópolis: Vozes, 2017. p. 48.

7 RÉMOND, René. Introdução à história do nosso tempo. 4. ed. Lisboa: Gradiva, 2011. p. 249.

8 CLARK, Christopher; KAISER, Wolfram. Culture wars: secular-Catholic conflict in nineteenth-century Europe. Cambridge: Cambridge University Press, 2003.

9 Segundo Hector Bruit, o nome América originalmente servia para designar a região sul daquilo que seria chamado de Continente Americano. No entanto, com o sucesso dos EUA, América passou a designar esse país, enquanto a região sul passou a ser identificada como América Latina. BRUIT, Hector H. A invenção da América Latina. In: ENCONTRO DA ASSOCIAÇÃO NACIONAL DE PESQUISADORES E PROFESSORES DE HISTÓRIA DAS AMÉRICAS, 5., 2002, Belo Horizonte. Anais [...]. São Paulo: ANPHLAC, 2002. p. 1-12. Disponível em: https://bit.ly/3iTkOWo. Acesso em: 14 jul. 2015. 
foram comuns a esta geografia político-religiosa. E o Brasil não foi exceção ${ }^{10}$.

Com efeito, nos séculos XVIII e XIX, a crescente afirmação da soberania dos Estados (e das nações) divergia das estruturas políticas, sociais e religiosas típicas do Antigo Regime, incluindo aquelas em que a Igreja ${ }^{11}$ exercia o seu poder temporal, particularmente em domínios como o do controle de extensos bens de mão morta e da educação. E, na era da fundação e/ou refundação dos Estados nacionais e de centralização do poder político, a crescente evocação do princípio da soberania nacional como fonte de poder exacerbou o aparecimento, em quase todos eles, de tendências regalistas ${ }^{12}$ e forte atitude antiultramontana ${ }^{13}$. Nesse contexto, os novos Estados começaram a

10 Cf. OLIVEIRA, Anderson José Machado de; RODRIGUES, Cláudia. El anticlericalismo en el Brasil. In: DI STEFANO, Roberto (org.). Pasiones anticlericales: uno recorrido iberoamericano. Bernal: Universidad Nacional de Quilmes, 2013. p. 191-244.

11 Utilizamos aqui o conceito de Igreja na acepção apresentada por Bronislaw Geremek, isto é, a Igreja como "um conjunto institucional capaz de organizar em torno de um sistema de crenças uma comunidade hierarquizada de fiéis, procedendo à estandardização de um sistema de sinais rituais". GEREMEK, Bronislaw. Igreja. In: ENCICLOPÉDIA Einaudi: mythos/logos, sagrado/ profano. Lisboa: Imprensa Nacional, 1987. v. 12.

12 Zília Osório de Castro escreveu que o regalismo era "a supremacia do poder civil sobre o poder eclesiástico, decorrentes da alteração de uma prática jurisdicional comumente seguida ou de princípios geralmente aceites, sem que haja uma uniformidade na argumentação com que se pretende legitimá-lo". CASTRO, Zília Osório de. Antecedentes do regalismo pombalino: o Padre José Clemente. In: POLÓNIA, Amélia. Estudos em homenagem a João Francisco Marques. Porto: Faculdade de Letras da Universidade do Porto, 2002. p. 323-331. Disponível em: https://bit.ly/2Izp2pT. Acesso em: 12 out. 2016.

13 Firmino Rodrigues da Silva (1816-1879), senador conservador pela província de Minas Gerais, foi um ultramontano assumido. Em discurso no Parlamento, analisou o conceito de "ultramontano", em que recuperou seu sentido original e etimologia. Declarou que o conceito nasceu em França, como criação dos chamados "galicanos", que definiram os católicos leais a Roma como ultramontanos. Para o senador, era um "tropo bem apropriado, visto ser Roma situada além das montanhas dos Alpes", e também em razão de que ultramontano "não é senão verdadeiro sinônimo de católicos apostólicos romanos, como segundo o mesmo tropo cismontano era do galicano". Então afirma categoricamente: "Sou verdadeiro ultramontano". E completa: "quem censura atualmente os seus adversários em matéria religiosa, nos julgando ultramontanos, pensa sem dúvida alguma a este respeito como os galicanos, e nos censura por sermos católicos apostólicos romanos". Entretanto, faz um reparo ao uso do conceito no Brasil, sugerindo novos 
enfrentar de maneira mais contínua o poder temporal eclesiástico, procurando limitar a sua dimensão e influência, de que era exemplo maior a Companhia de Jesus.

As tendências regalistas e antiultramontanas se expressaram de variadas maneiras, em contextos diversos ${ }^{14}$. Seus objetivos essenciais eram: nacionalizar os bens eclesiásticos, lançar bases tendentes a criar uma "educação nacional" (gratuidade, obrigatoriedade e, para os mais radicais, laicidade do ensino), defender a institucionalização do registro civil obrigatório, contestar o cariz ultramontano da organização eclesiástica, defender igrejas nacionais e, na fase mais adiantada, reivindicar o casamento civil, a secularização dos cemitérios, a elegibilidade dos acatólicos e a separação entre Igreja e Estado.

Particularmente nos Estados europeus, e em especial nos latino-americanos de tradição católica, atravessados por processos de emancipação política face a suas metrópoles e heranças coloniais, as divergências acima assinaladas foram muito relevantes ${ }^{15}$. O que não admira, porquanto todos necessitavam - e cada qual à sua maneira - reforçar os instrumentos de poder, inclusive os simbólicos, desiderato esse obstaculizado pela Igreja, instituição de vocação transnacional, ou melhor, ultramontana, que lidava mal com os valores defendidos pela modernidade política.

Ora, nesse pano de fundo é que se desenvolverá, em diversos Estados europeus e americanos, as chamadas "questões religiosas", conflitos diversos entre o poder temporal e espiritual. Como procura-

tropos: "não devia, porém, ser aplicado o mesmo tropo, porque a posição de Roma acerca do Brasil não é a mesma relativa à França. Devíamos então em consequência dessa diferença e mais concernente a retórica sermos denominados ultramarinos ou transatlânticos". Os opositores dos ultramontanos, por conseguinte, eram rotulados de "antiultramontanos". Cf. BRASIL. Annaes do Senado Imperial (ASI). Sessão em 1 de julho de 1874, v. I, p. 7-13. Rio de Janeiro: Typ. Nacional. Disponível em: https://bit.ly/3k3fiit. Acesso em: 17 jul. 2017. Doravante ASI.

14 SANTIROCCHI, Ítalo Domingos. Questão de Consciência: os ultramontanos no Brasil e o regalismo do Segundo Reinado (1840-1889). Fino Traço: Belo Horizonte, 2015.

15 BARNADAS, Josep. A Igreja Católica na América espanhola colonial. In: BETHELL, Leslie (org.). História da América Latina: América Latina colonial. São Paulo: Edusp, 1998. v. 1. p. 521-551. 
remos demonstrar neste artigo, na sua manifestação em diversos espaços, essa problemática sofrerá metamorfoses indissoluvelmente ligadas aos diferentes processos de construção dos Estados nacionais.

\section{O pontificado de Pio IX e o confronto com a modernidade}

Entre os séculos XVIII e XIX, as mudanças políticas, sociais, econômicas e culturais contribuíram para intensificar o processo de secularização na Europa e no continente americano ${ }^{16}$, tendo como resultado maior autonomização do indivíduo e da sociedade em relação à Igreja, embora com especificidades e ritmos diferentes. Com efeito, essa nova realidade - que adquiriu feições concretas com as diversas revoluções políticas e sociais, com a revolução industrial, com o crescimento das cidades e das culturas urbanas etc. -, produziu transformações na percepção do mundo e no sentido da vida e do viver em comum. As novas ideias tomaram corpo em conflitos concretos. Materializa-se uma nova conjuntura política e social que tinha como propósito romper as amarras do Antigo Regime, e foi com esse objetivo que eclodiram diversas revoluções nos séculos XVIII e XIX, destacando-se a Revolução Francesa, ou melhor, "as revoluções modernas em França" (1789, 1848, 1871) ${ }^{17}$.

Ora, a Igreja Católica tinha interesses associados ao Antigo Regime e ao mundo colonial, o que a fez legitimar sua ordem sacro-na-

16 Fernando Catroga escreve que a secularização percorreu "um longo caminho": desenvolvendo-se desde a Alta Idade Média, desaguou na modernidade, "provocando a progressiva autonomia da razão humana, da natureza e da liberdade, exemplarmente expressa na crítica kantiana à especulação metafísica, na redução da natureza ao reino da fenomenalidade físico-matemática e na incondicional relevância da acção humana na construção do seu próprio destino". CATROGA, Fernando. A militância laica e a descristianização da morte em Portugal: 1865-1911. 1988. Tese (Doutorado em História Moderna e Contemporânea) - Departamento de História da Universidade de Coimbra, Coimbra, 1988. 2 v. p. 21.

17 Ibidem, p. 76. 
tural subjacente ${ }^{18}$, gerando a oposição das forças "progressistas" da sociedade moderna.

Não cairíamos em grande erro se afirmássemos que o papa que melhor encarnou o enfrentamento da Igreja Católica contra o mundo moderno foi Pio IX (1792-1878). O seu longo pontificado (1846-1878) provocou grandes controvérsias nas relações da Igreja com diversos Estados europeus. Entretanto, a ascensão de Giovanni Maria Mastai Ferretti ao papado havia gerado muitas expectativas e esperava-se que ele reconciliasse a Igreja com as instituições e as ideias liberais, o que de fato aconteceu nos primórdios do seu governo. Porém, a realidade social e política europeia estava mudando - revoluções de 1848, guerra da unificação italiana, geminação da questão religiosa com a questão social, progressão do saber filosófico rumo aos vários socialismos e positivismos -, o que rapidamente suscitou respostas de orientação conservadora e atitudes declaradamente antimodernas. O contexto europeu e, mais especificamente, o italiano lançam luz sobre as razões que levaram o referido papa a colocar-se frontalmente contra aspectos da modernidade.

Com efeito, os conflitos envolvendo diretamente a Igreja e os defensores da unificação italiana começaram em 1848. Nesse ano, sentindo-se em perigo, Pio IX abandona Roma e foge para Gaeta, após o assassinato, por revolucionários, do ministro dos Estados Pontifícios, Pellegrino Rossi (1787-1848). Com a saída do papa da cidade de Roma, em 19 de fevereiro de 1849, foi proclamada a República Romana, com o fim, ainda que momentâneo, do poder temporal dos papas. Pio IX solicitou então o apoio militar de Luís Napoleão, que enviou um exército e reconquistou Roma, reinstalando o papa no Vaticano em $1850^{19}$.

18 A preservação do status quo político do Antigo Regime equivalia à preservação dos interesses materiais da Igreja. No caso do mundo colonial, a posse de enorme quantidade de terras, casas e escravos por todo o território "nacional".

19 NETO, Vítor. O Estado, a Igreja e a sociedade em Portugal (1832-1911). Lisboa: Imprensa Nacional, 1998. p. 164. 
Em 1859, eclodiram conflitos armados entre o reino da Sardenha e a Áustria, enquanto elementos piemonteses provocaram insurreições em várias regiões italianas, atingindo, inclusive, territórios pontifícios. Pio IX reagiu com a chamada "excomunhão maior", atingindo todos os revolucionários que participaram diretamente da campanha. Não obstante, Giuseppe Garibaldi (1807-1882) iniciou uma campanha armada, partindo do Sul, com o objetivo de tomar Roma. Mas antes de Garibaldi entrar efetivamente na Cidade Eterna, Camillo Benso - conde de Cavour (1810-1861) e primeiro ministro do reino de Piemonte - anexou algumas terras da Igreja, incorporando-as ao reino da Itália, então em formação. Em princípios de 1861, Cavour tentou convencer o papa a renunciar ao poder temporal, prometendo plena liberdade para a Igreja. As tentativas não tiveram nenhum resultado e, em 7 de março de 1861 foi proclamado o reino de Itália. No entanto, ainda faltava anexar Veneza e Roma ${ }^{20}$.

Em 1870, a França estava em guerra com a Prússia. A derrota francesa teve como consequência imediata a retirada das guarnições que protegiam o Estado Pontifício. Era o sinal verde para o ataque decisivo das tropas italianas, que chegaram às portas de Roma a 16 de setembro de 1870. Em 20 de setembro, os soldados entraram na cidade. Estava concluído o processo de unificação da península italiana. Em 1871, Roma tornou-se a capital de Itália, substituindo Florença. Doravante, o papa assumiria a condição de prisioneiro do Vaticano. Não cessaria um só instante de protestar contra o que considerava uma gravíssima violação do direito do Estado Pontifício (a "Questão Romana" só teve um desfecho em 1929, com os tratados de Latrão) ${ }^{21}$.

À condicionalidade política juntou-se a contraofensiva teológica que Pio IX lançou desde meados do século contra o avanço do pensamento racionalista e cientificista, contra as teses em que se assentavam as ideologias democráticas, liberais e socialistas, bem como todas as propostas daqueles que, no seio da Igreja, propugnavam uma

20 MATOS, op. cit., p. 109-110.

21 Ibidem, p. 111. 
maior abertura aos novos tempos. A tudo isto responde o papado com a dogmatização da Imaculada Conceição (1854), com a encíclica anatematizadora da modernidade, Quanta cura e, no mesmo sentido, com a bula Syllabus e a proclamação da infalibilidade papal (Concílio Vaticano I, 1869-1870).

Bronislaw Geremek, no verbete "Igreja", da clássica enciclopédia Einaudi, escreveu que, "para a Igreja, era necessário confrontar-se com a ideologia liberal”, relembrando que, conforme a condenação $80^{a}$ do Syllabus, seria um erro afirmar que "o Pontífice romano pode e deve conciliar-se e transigir com o Progresso, com o Liberalismo e com a Civilização moderna”. Por conseguinte, em sua intransigência contra o liberalismo e outras ideologias anatematizadas no Syllabus, a Igreja condenou, por um lado, a fórmula de Cavour, "Igreja livre num Estado livre", expressão que resumia a atitude da "burguesia liberal que vê na Igreja um poderoso suporte da sociedade política tradicional" e, por outro lado, anatematizou também a proposta de Lamennais $^{22}$, que visava à "cristianização do liberalismo", tentativa de adaptar "a Igreja às novas exigências" do mundo moderno, "proposta solenemente recusada por Gregório XVI na encíclica Mirari vos (1832)"23. Com efeito, este documento precursor de Quanta cura e do Syllabus refutava categoricamente qualquer compromisso do poder espiritual com o liberalismo. A Igreja não podia aceitar a "monstruosidade da liberdade de imprensa", assim como não deveria acolher no seu seio as teses da separação da Igreja e do Estado. Todas essas liberdades eram vistas como uma consequência da "liberdade do erro", que estaria trazendo grandes "males" para a sociedade e para a Igreja ${ }^{24}$.

22 Hughes-Felicité Robert de Lamennais (1782-1854) foi um padre ordenado em 1816, notório defensor do catolicismo liberal francês.

23 GEREMEK, op. cit., p. 210.

24 PAPA GREGÓRIO XVI. Mirari Vos: carta encíclica promulgada em 15 de agosto de 1832, sobre os principais erros de seu tempo. Disponível em: https://bit.ly/3nU12oK. Acesso em: 12 ago. 2016. 
Pio IX recuperou e ampliou a doutrina da Mirari vos com a encíclica Quanta cura, publicada em 8 de dezembro de 1864. Nela, o papa condena:

os principais erros modernos: o racionalismo, que chega até a negar a divindade de Cristo; o galicanismo, que exige uma sanção do poder civil para o exercício da autoridade eclesiástica; o estatismo, que visa ao monopólio do ensino; o socialismo, que pretende submeter totalmente a família ao Estado, ao direito civil; enfim, e sobretudo, o naturalismo, que considera como um progresso que a sociedade humana seja constituída e governada sem ter em conta a religião. ${ }^{25}$

Pio IX, ao justificar a publicação da encíclica, declara ser um dever do ministério apostólico seguir os passos dos predecessores que desempenharam com êxito a defesa da "sacrossanta religião católica" e condenar "os erros principais de nossa época tão desgraçada", exortando os fiéis "para que abominassem tão horrendas doutrinas e não se contagiassem delas"26.

Como complemento à bula Quanta cura, Pio IX publicou o Syllabus, cujo conteúdo consistia num catálogo de 80 proposições consideradas inaceitáveis para um católico romano. Elas são classificadas em quatro grandes blocos: as filosofias modernas (entre elas, o panteísmo, o naturalismo, o racionalismo, o indiferentismo, o socialismo, o comunismo); a ética laica, com referência especial ao casamento civil; as relações entre Estado e Igreja (separatismo dos dois poderes); e as liberdades modernas, como as liberdades de consciência, de culto, de imprensa e de opinião $0^{27}$. Conforme escreveu Ubiratan Borges de Macedo, "essa atitude de endurecimento era a resposta ao Congresso

25 MARTINS, António Manuel. Recepção em Portugal das encíclicas sobre o liberalismo Mirari Vos, Quanta Cura e Immortale Dei. Lusitania Sacra, Lisboa, v. 2, n. 1, p. 41-80, 1989. Disponível em: https://bit.ly/2T43ALj. Acesso em: 12 ago. 2016. p. 55.

26 PAPA PIO IX. Quanta Cura: carta encíclica promulgada em 8 de dezembro de 1864, sobre os principais erros da época. Disponível em: https://bit.ly/37aMbZK. Acesso em: 25 out. 2015.

27 PAPA PIO IX. Syllabus: contendo os principais erros da nossa época, promulgada em 8 de dezembro de 1864. Disponível em: https://bit.ly/3nU120K. Acesso em: 12 ago. 2016. 
Católico Internacional de Malines [Bélgica, 1862], reunido pelos católicos liberais, no qual Montalembert ${ }^{28}$ fizera um último esforço para reconciliar a Igreja com o mundo liberal", à volta da divisa "Igreja livre no Estado livre"29.

Outra decisão importante tomada por Pio IX foi convocar o Concílio Vaticano I (1869-1870), iniciativa que, como se viu, decorreu num contexto bastante delicado, isto é, no momento que antecedeu o desfecho do processo de unificação italian $a^{30} \mathrm{e}$ a guerra franco-prussiana, cujo desfecho conduzirá à Comuna de Paris (1871) e a uma crise que, no decurso do processo, culminará na queda da monarquia e na instauração da república em França.

Um dos principais resultados do Concílio foi a aprovação da infalibilidade papal, dogma que veio enfraquecer o magistério dos concílios eclesiásticos, visto que o papa era agora, quase exclusivamente, a autoridade suprema em questões de fé e moral. Ora, conforme escreveu Bronislaw Geremek:

a proclamação solene da infalibilidade do papa pelo Concílio Vaticano I (1870) foi tomada pela opinião pública dos países liberais como um reforço do caráter monárquico e centralizante do poder eclesiástico. Mas poucos meses depois da promulgação da constituição Pastor aeternus, o papa perdeu o seu poder temporal sem que a usurpação de Vítor Emmanuel II provocasse indignação entre os povos católicos da Europa $^{31}$.

28 O político e polemista francês Charles Forbes René de Tryon (1810-1870), conde de Montalembert, foi o mais notável representante do catolicismo liberal de sua época.

29 MACEDO, Ubiratan Borges de. A idéia de liberdade no século XIX: o caso brasileiro. Rio de Janeiro: Expressão e Cultura, 1997. p. 130.

30 Conforme análise de David Sampaio Barbosa, "a convocação do Concílio Vaticano I para o fim do ano de 1869, na óptica do poder político, discretamente presente nas pessoas dos representantes diplomáticos, prendia-se inevitavelmente com a delicada questão do poder temporal do papa”. SAMPAIO, David. O Concílio Vaticano I e o governo português (1869-1870). Lusitania Sacra, Lisboa, v. 2, n. 1, p. 11-40, 1989.

31 GEREMEK, op. cit., p. 211. 
Muitos governos regalistas e setores liberais da sociedade europeia e americana entenderam que essas novas dogmatizações da Igreja de Roma se materializariam em intervenções indevidas do clero, isto é, em clericalismos. Realidade que geraria, como de fato gerou, intensa oposição em diversos Estados em vias de fortalecimento, isto é, anticlericalismos.

Antes de avançarmos para a análise das conflitualidades entre Estados e Igreja de Roma, convém esclarecer melhor os dois conceitos operativos mencionados acima.

\section{3. "Os irmãos siameses": anticlericalismo e clericalismo}

Sobre a origem destes conceitos, René Rémond escreve que "o aparecimento na linguagem política dos vocábulos clerical e anticlerical, clericalismo e anticlericalismo, é quase concomitante: opera-se entre os anos 1850-1870"32. Por sua vez, Fernando Catroga afirma que o "termo 'clericalismo', ao que parece, precedeu o de 'anticlericalismo". Entretanto, "ambos funcionavam como irmãos siameses", pois o primeiro teve necessariamente de gerar o segundo"33. No Brasil, a partir da década de 1870, os termos "clericalismo" e "clericalização" foram amplamente utilizados no parlamento imperial. Por conseguinte - tanto na experiência francesa, portuguesa e brasileira -, é razoável aceitar como recente a adjetivação e substantivação de, respectivamente, "anticlerical" e "anticlericalismo", embora como prática social sejam realidades muito mais antigas: na Europa remontam à Idade Média e no Brasil ao período colonial.

Em razão de "anticlericalismo" ser um conceito polissêmico ${ }^{34}$, cabe aqui consignar algumas de suas acepções, em particular a de

32 RÉMOND, René. L’Anticlericalisme en France: de 1815 à nos jours. Paris: Fayard, 1976. p. 9-10.

33 CATROGA, op. cit., p. 305.

34 Sobre as várias acepções do lexema "anticlericalismo", além das obras já citadas, cf. também: CATROGA, op. cit.; ABREU, Luís Machado de; MIRANDA, António José Ribeiro (org.). O anticlericalismo português: história e discurso: actas do colóquio. Aveiro: Universidade de Aveiro, 
sua definição como anticlericalismo popular (muito mais antigo) e político (que se desenvolveu na viragem do século XVIII para o XIX). O primeiro é mais difuso e manifesta-se em atitudes nascidas no seio do próprio cristianismo, sendo por isso um fenômeno interno, expresso normalmente na rejeição de certos dogmas, na oposição ao abuso de poder do clero e a seus comportamentos morais. Este tipo de anticlericalismo recebeu forte impulso com os novos regulamentos emanados do Concílio de Trento (1545-1563), que deram força ao celibato clerical e à confissão auricular, práticas que causavam receio, sobretudo aos homens ${ }^{35}$. No fundo, ele manifestava as dificuldades que a prática do cristianismo ocidental com nuances pagãs sentia em face da cultura letrada e eclesial do clero, mesmo que não colocasse em causa a Igreja, e muito menos a religião.

No contexto da progressiva secularização do Estado, o anticlericalismo político indicia um conflito secularizador mais profundo, pois foi teorizado por elites ilustradas que, "com a sua inserção em ideologias culturalmente mais inovadoras e politicamente mais avançadas", recebeu "novos impulsos e enquadramentos teóricos". Seja como for, nos seus primórdios iluministas e liberais, seu conflito com a Igreja também não punha em causa a verdade do cristianismo como religião revelada, nem a sua validade como fonte última da ética e da moral, nem ainda sua vivência ritualística e seu crucial papel na reprodução dos elos de sociabilidade ${ }^{36}$. No entanto, a radicalização da questão religiosa na segunda metade do século XIX em países católicos, interligada com questões políticas (monarquia ou república)

2002; ABREU, Luís Machado de. Ensaios anticlericais. Lisboa: Roma Editora, 2004; LALOUETTE, Jacqueline. La république anticléricale, XIXe-XXe siècles. Paris: Seuil, 2002.

35 CATROGA, op. cit., p. 7; Joyce Firstenberg Riegelhaupt, dissertando também sobre o anticlericalismo popular, afirma que "existe uma gama de críticas anticlericais que são explicitamente dirigidas contra a maneira como o padre local desempenha os seus deveres religiosos e que muitas vezes parecem pôr em causa a estrutura sacerdotal do catolicismo. $O$ alvo, nestas atitudes 'anticlericais', é o padre propriamente dito, e não a instituição da Igreja ou a religião". RIEGELHAUPT, Joyce Firstenberg. O significado religioso do anticlericalismo popular. Análise Social, Lisboa, v. 18, n. 72-74, p. 1213-1230, 1982.

36 CATROGA, op. cit.. 
e sociais (socialismo, anarquismo), e também com a crescente atração pelas filosofias racionalistas e críticas, fizeram que, ao anticlericalismo político de tendência liberal e, em última análise, católico, viesse se juntar um "anticlericalismo livre-pensador, de base não só agnóstica, mas também ateia" ${ }^{37}$.

O anticlericalismo também poderá ser melhor apreendido se o trabalho historiográfico recorrer a uma ideia clara do sentido que o investigador atribui ao conceito de clericalismo. E, neste campo, teremos sempre em mente a definição oferecida por um dos principais doutrinadores franceses do livre-pensamento: o clericalismo é "la prétention d'une minorité à dominer la majorité au nom d'une religion"38. E terá sido este entendimento o que ganhou mais luz e força com a célebre afirmação feita em 1872 pelo grande líder republicano francês Léon Gambetta (1838-1882): "le cléricalisme, voilà l'ennemi"39. Por sua vez, tal definição não pode ser confundida com divisas mais radicais e ateias, como o lema de Pierre-Joseph Proudhon (1809-1865): "ni Dieu, ni prêtres"40, que surge no contexto em que a questão religiosa tendia a fundir-se com a questão social.

René Rémond também postula que o "l'anticlericalisme est plus que une idéologie negative"41. Esse movimento contém em si uma ideologia positiva, constituindo um campo fértil de proposições, sobretudo daquelas voltadas para a ação política, particularmente em

37 CATROGA, op. cit., p. 11. Cf. também FERREIRA, António Matos. Anticlericalismo. In: AZEVEDO, Carlos Moreira (dir.). Dicionário de história religiosa de Portugal. Lisboa: Círculo de Leitores, 2001. v. A-C. p. 80.

38 BUISSON, Ferdinand apud CATROGA, Fernando. Entre deuses e césares: secularização, laicidade e religião civil. Coimbra: Almedina, 2006. p. 303. A trajetória de Ferdinand Buisson, segundo Jacqueline Lalouette, sublinha uma aliança ideológica entre um deísmo vago, certo "sentimento religioso" e uma fé secular. LALOUETTE, op. cit., 2002.

39 LALOUETTE, Jacqueline. El anticlericalismo en Francia, 1877-1914. Ayer, Madrid, n. 27, p. 15-38, 1997. p. 16.

40 CATROGA, op. cit., p. 326.

41 RÉMOND, René. L’Anticlericalisme en France: de 1815 à nos jours. Paris: Fayard, 1976. p. 4. 
defesa de um ideal de Estado livre de intervenções clericais ${ }^{42}$, tendo como bandeira de luta a defesa do Estado secularizado, com todos os seus componentes: livre consciência, liberdade de culto, separação entre o temporal e o espiritual, registro civil, casamento civil, ensino laico, secularização de todas as esferas públicas etc. Em função dessa compreensão do anticlericalismo como proponente de uma nova cosmovisão (mundividência), Fernando Catroga sustenta que essa ideologia é um fenômeno totalizante, isto é, uma visão de mundo que se propõe a explicar todas as dimensões da realidade humana (sociedade, economia, religião etc) ${ }^{43}$.

Perceber como os anticlericais se autorrepresentaram é outro aspecto importante do fenômeno. René Rémond chama a atenção para o fato de que eles "ne se désignent pas spontanéament ainsi: ils s`appelleront libres penseurs, racionalistes, ils se diront attachés à l'indépendance de la société civile, partisans de la séparation des Églises et de l'État, hostiles à l'ingérence du clergé dans la vie privée ou les activités collectives; anticléricaux, rarement" ${ }^{\prime 4}$. Portanto, não apenas a dimensão negativa de "anti" define os anticlericais, mas também o conjunto de proposições positivas.

Portanto, o clericalismo é aqui entendido como o conjunto de intervenções do clero na vida política, tradição histórica que - em fins do século XVIII e por todo o seguinte-, passou a ser considerada inadequada aos novos tempos. Por sua vez, o anticlericalismo é a ideologia que enfrentará essa ingerência do clero nas diversas esferas da vida pública e no Estado.

A dimensão combativa dos anticlericais, assim como suas propostas de transformação nas relações entre os Estados e a Igreja de Roma, é claramente identificável em diversos espaços ao longo do

42 Luís Machado de Abreu escreve que "a carga negativa transportada pelo prefixo 'anti', com que foi cunhado o termo no século XIX, oculta a riquíssima diversidade de elementos positivos que ele igualmente contém, nomeadamente como agente de mudança e promotor de programas de renovação da existência civil e da vida social”. Cf. ABREU, op. cit., p. 13.

43 CATROGA, op. cit. ABREU; MIRANDA, op. cit.

44 REMOND, op. cit., p. 8. 
século XIX. Na realidade brasileira é possível perceber, a partir das décadas de 1860 e 1870, a intensificação da militância anticlerical, sobretudo no Parlamento Imperial brasileiro.

\section{4. $O$ anticlericalismo no Parlamento brasileiro: sintonizado}

\section{como "mundo"}

Na década de 1860 e sobretudo na de 1870, ocorreu no Brasil Imperial - assim como em outros países católicos da Europa e das Américas - um assomo ultramontano, com a ascensão de vários padres "romanizadores" ao episcopado, curiosamente indicados pelo próprio imperador ${ }^{45}$. Ora, essa nova realidade criou nos espíritos mais livres a sensação de que se assistia a uma "invasão ultramontana". Sensação que foi se transformando em convicção ao longo da campanha contra o mundo moderno durante o papado de Pio IX.

Pois bem, esse revigoramento dos partidários dos interesses da Santa Sé no Brasil desencadeará importantes desentendimentos entre a Igreja e o Estado, culminando na "questão dos bispos" (18721875) - episódio fulcral da longa questão religiosa brasileira. Esse conflito - em que a desobediência à Constituição e às leis do país foi considerada reflexo da obediência a uma instância de poder maior, o Papa, agora portador da infalibilidade ex cathedra - teve como desfecho a prisão de dois bispos e, após um ano, a anistia concedida por $\mathrm{d}$. Pedro II. Desde então, as relações entre os dois poderes ficaram sob o signo da suspeição.

As mudanças conjunturais que ocorreram na política imperial nas décadas de 1860 e 1870 também contribuíram de forma significativa para intensificar os conflitos entre anticlericais e ultramontanos. Com efeito, o meio político-partidário no Brasil estava passando por uma inflexão desde 1868, quando ocorreu uma forte dissensão entre os conservadores e liberais, com intensas repercussões par-

45 SANTIROCCHI, op. cit., p. 104-105. 
lamentares, culminando no surgimento de tendências partidárias radicais/reformistas que, a curto prazo, formaram agremiações políticas questionadoras do status quo hegemônico. Referimo-nos ao movimento republicano, que foi paulatinamente se fortalecendo e se consolidando em partidos provinciais. Movimento que, entre outras bandeiras, passou a defender a separação entre o Estado e a Igreja Católica.

Mesmo entre os que não abraçaram o republicanismo num primeiro momento, é possível encontrar, já na década de 1870, posições anticlericais bem radicais - nomeadamente a dos deputados Silveira Martins, Rui Barbosa e Joaquim Nabuco, entre outros que, embora não contestassem o sistema monárquico, questionavam algumas das suas instituições, entre elas o catolicismo romano como religião oficial.

Esse movimento anticlerical - republicano e liberal - elegerá a separação entre a Igreja e o Estado como medida prioritária. Era preciso desatar o nó que enlaçava as duas instituições. E a urgência impunha-se não só para pôr fim aos potenciais conflitos, mas devido à necessidade que o país tinha de recrutar imigrantes num contexto de crise do sistema escravocrata, tarefa dificultada, pelo menos em relação à imigração de não católicos, pelas limitações de direitos civis (como a do acesso ao funcionalismo público) impostas pelos que não perfilhavam a religião de Estado.

Por conseguinte, a conjuntura político-religiosa das primeiras duas décadas do Segundo Reinado foi determinante para os contornos futuros do anticlericalismo no parlamento imperial. Em outros termos, a eclosão da questão dos bispos, ao lado do novo radicalismo anticlerical no meio político (republicano e liberal), associada com a necessidade de imigrantes, agudizou as tensões entre a Igreja Católica romana e o Estado imperial, fazendo irromper um conjunto de reivindicações bastante progressistas para a época. A par do antijesuitismo, do anticongreganismo e do anticlericalismo liberal, ganhou força a luta pela separação da Igreja e do Estado. Ora, se esse objetivo era crucial para respeitar uma ideia mais plena de liberdade religiosa 
pleiteada pelos acatólicos ${ }^{46}$, não deixa de ser relevante que os avanços concretos tivessem dado prioridade ao registro civil, ao casamento civil e à secularização dos cemitérios, e não tanto, como ocorreu em França e viria a acontecer em Portugal, ao ensino leigo.

Ora, se a agenda anticlerical era frontalmente contra a ultramontana, também era diferente e, em muitos pontos, antagônica ao legado regalista, como as consignas que estiveram em alternativa bem revelam: "Igreja livre no Estado livre", "Igrejas livres no Estado livre" (que acabou por vencer) e "Igrejas livres no Estado indiferente ou neutro".

Com efeito, tanto a questão dos bispos quanto a militância anticlerical parlamentar contribuíram para uma certa dessacralização do poder monárquico na década final do Império. Situação que deu azo ao movimento republicano, que - imbuído de certo ecletismo de fundo positivista, ou de um positivismo religioso - encontrou, nos meios intelectuais e militares, uma massa crítica suficiente para liderar, nos núcleos urbanos, algo que não foi propriamente uma revolução, mas um golpe de Estado, de onde saiu a implantação da República em 1889.

Esse foi o pano de fundo com que os republicanos tiveram de lidar uma vez chegados ao poder. E, se estes deram a primazia à institucionalização e constitucionalização do novo regime, é nossa intenção aqui mencionar o cordão umbilical que conectou este processo com o da solução da questão religiosa, pois a separação entre as Igrejas e o Estado foi decretada menos de dois meses após o advento da República - por meio do Decreto 119-A de 7 de janeiro de 1890 - e, na sequência, surgiram diversas leis secularizadoras, tais como a do casamento e do registro civil, da secularização dos cemitérios, do ensino leigo na capital etc. Naturalmente, tais medidas suscitaram apoio e oposição, tensão rica de significado político e cultural.

46 VIEIRA, David Gueiros. O problema do direito civil do imigrante e a queda do gabinete de Olinda, 1866. Revista de Informação Legislativa, Brasília, DF, v. 11, n. 44, p. 153-160, 1974. 
Como ficará mais evidente à frente, o anticlericalismo praticado no parlamento imperial e no Governo Provisório (1889-1891) da República brasileira, e que culminou na separação entre a Igreja e o Estado - 15 anos antes da França e 21 antes de Portugal, não estava desconectado do que ocorria na Europa e em outras partes da América.

\section{O Anticlericalismo europeu: ecos no Parlamento brasileiro}

As decisões tomadas e resoluções adotadas durante o pontificado de Pio IX - materializadas na encíclica Quanta cura e no Syllabus, entendidas como uma ofensiva da Igreja contra os valores essenciais da modernidade - tiveram fortes repercussões em diversos Estados europeus, bem como no continente americano, especialmente nos países católicos ${ }^{47}$. Tais medidas eclesiásticas sofreram forte oposição, nos espaços mencionados, dos próprios católicos de orientação mais liberal, assim como de grupos mais radicais, como os livres-pensadores, e foram um fator no reavivamento e incremento da questão religiosa, agora num contexto mais secularizado e influenciado por ideias de emancipação política e social.

O presente artigo pode ser considerado um spin-off de nossa tese doutoral ${ }^{48}$. Ao estudarmos as incidências do anticlericalismo no Parlamento brasileiro, constatamos que muitos deputados e senadores, recorrentemente - no afã de comparar com a realidade nacional -, faziam referência aos embates anticlericais em outros espaços, tanto americano como europeu. Por diversas razões, no momento da escri-

47 Vale a pena lembrar, como escreveu o brasilianista Thomas Bruneau, que, antes de se tornar Papa, Pio IX "visitou a América Latina e tomou conhecimento dos problemas do continente. Uma consequência disso foi a fundação do Colégio Pontifício Pio Latino Americano, em Roma, em 1858, destinado especialmente aos padres latino-americanos". BRUNEAU, Thomas. O catolicismo brasileiro em época de transição. São Paulo: Loyola, 1974. p. 58.

48 SILVA, Ivo Pereira da. O Anticlericalismo Político no Parlamento Brasileiro (1868-1892). Tese (Doutorado em História Contemporânea), Faculdade de Letras da Universidade de Coimbra UC, Coimbra, Portugal, 2018. 
ta da tese, não foi possível envidar uma pesquisa mais densa sobre as outras realidades históricas mencionadas pelos parlamentares. Este trabalho, apesar de ter autonomia em relação àquele, de certa forma o expande.

A documentação utilizada na confecção deste trabalho deixou claro que os deputados e senadores brasileiros estavam informados sobre os movimentos dos livres-pensadores, dos anticlericais e dos católicos liberais em alguns países europeus, nomeadamente Bélgica, Alemanha, França e Portugal. O caso belga era o mais recorrente nos debates, o caso alemão era utilizado mais pelos ultramontanos, como exemplo que não deveria ser seguido pelo governo brasileiro e, em menor escala, surgiam referências à França. Portugal, apesar de ser o que menos aparecia na documentação, teve uma longa e rica militância anticlerical. Também foi incluído o caso dos Estados Unidos, que, por ser um Estado de tradição protestante, funciona como contraponto ao modelo católico de relação entre Estado e Igreja.

Os parlamentares brasileiros recorrentemente citavam a Bélgica para sustentar os seus argumentos, seja para defender um Estado mais secularizado ou para ressaltar o exemplo de um lugar onde havia uma forte presença dos católicos liberais, menos afeitos ao ultramontanismo. De qualquer forma, a Bélgica tornou-se uma referência para os opositores do clericalismo no Império brasileiro.

Desde a independência da Bélgica do domínio holandês, em 1830, existia uma significativa a proximação entre católicos e liberais. De fato, "desta convergência de interesses resulta uma Constituição [1831] que garantia a liberdade de ensino, de reunião e de imprensa"49. A Bélgica, ao lado da França, torna-se um país vanguardista na luta contra o clericalismo e o ultramontanismo, sendo que os ataques a Roma eram desferidos pelos católicos liberais, assim como pelos livres-pensadores. No entanto, assim como em outros países, esse processo também sofreu resistências. O clero conservador e favorável a Roma resistia aos ventos do liberalismo político e religioso.

49 MARTINS, op. cit., p. 53. 
Nesse contexto de debates decorre em Malines, em 20 de agosto de 1862, o I Congresso dos Católicos Belgas, um dos mais importantes encontros de católicos liberais da Europa no século XIX. "Aí Montalembert faz a defesa do regime liberal, preferível ao absolutista. De igual modo, elogia os católicos belgas e reprova os católicos de outros países de se não darem conta de que o antigo regime não admite nem a igualdade, nem a liberdade política, nem a liberdade de consciência"so. A conclusão do argumento era que os católicos, ao apoiarem o ultramontanismo, estavam fortalecendo o Antigo Regime.

À tradição do forte movimento católico liberal, soma-se o movimento livre-pensador. Fernando Catroga relata que na Bélgica, no início dos anos 1860, foram criadas duas sociedades de livres-pensadores. A primeira, a sociedade Les Libres Penseurs, era mais extremista e aproximava-se das ideias de Pierre-Joseph Proudhon (1809-1865), esboçadas no lema "Dieu, c'est le mal". Por sua vez, em 1863, foi criada a organização Libre Pensée, menos extremista, e "que contava com o apoio determinante da maçonaria e de alguns setores mais progressistas da burguesia da capital belga". A existência dessas sociedades evidenciava duas tendências dentro do movimento livre-pensador belga: a "tendência materialista, agnóstica e positivista", que secundarizava "a influência do espiritualismo e dos partidários da religião natural" e reforçava "o peso dos democratas e socialistas" Tudo isso revela como, nas décadas de 1860 e 1870, o anticlericalismo dos livres-pensadores belgas foi bastante ativo, exercendo grande influência na Europa, sobretudo ao promover congressos, nacionais e internacionais, cujo objetivo era divulgar as ideias e os valores desses pensadores radicais.

Como mencionado, a Bélgica e sua constituição liberal eram uma das referências para os livres-pensadores brasileiros. Em 1880, em

50 Ibidem, p. 54.

51 CATROGA, Fernando. O livre-pensamento contra a Igreja: a evolução do anticlericalismo em Portugal (séculos XIX e XX). Revista de História das Ideias, Coimbra, v. 22, p. 255-354, 2001. p. 260-261. 
discurso na Câmara dos Deputados para defender a secularização dos cemitérios, Rui Barbosa declara:

Cheguei, portanto, Sr. Presidente, ao ponto em que posso assentar a minha conclusão final [...]: o liberalismo incompatível com o dogma pontifício não é a revolução demagógica, arrasando os templos, profanando os altares, espingardeando os levitas sagrados, confiscando a propriedade, conculcando crenças, direitos e tradições: o da convenção de 1793 ou a comuna de 1870. Não! É a essência e a forma secular das instituições sociais e políticas em nosso tempo; são as bases de todas as constituições contemporâneas, da constituição inglesa, da constituição belga, da constituição italiana, da constituição brasileira (já de propósito não quero aludir às republicanas); são as chamadas garantias constitucionais, sem as quais não há povo livre nem povo soberano; é, enfim, essa soma de ciência, individualismo e democracia, cuja supressão, se fosse possível consegui-la, reabismar-nos-ia na idade média (sic), o Éden da Igreja..$^{52}$ (Grifo nosso).

Mesmo estando presente nos discursos dos parlamentares brasileiros, poucos vínculos formais foram desenvolvidos entre os anticlericais nacionais e os livres-pensadores belgas. Apenas no século XX foi que os estreitamentos começaram a ocorrer. Em 1912, os livres-pensadores do Brasil integraram-se a organizações internacionais, como a Fédération Internationale de la Libre Pensée, criada em Bruxelas, em 1880:

O Brasil integrou esta Federação no início do século XX, uma vez que se constituíam as ligas anticlericais em oposição à ingerência clerical na vida social e política do país. Nas cidades onde se instalaram se aproximavam muito dos meios maçônicos. Em particular, a Liga Anticlerical do Rio de Janeiro, fundada em 1911, se filiou à Federação Internacional do Livre-Pensamento em 1912. Pode-se seguir a

52 BRASIL. Annaes da Camara dos Deputados (ACD). Sessão 27 de julho de 1880, tomo I, Apêndice, p. 149. Rio de Janeiro: Typ. Nacional, 1880. Disponível em: https://bit.ly/351pO6r. Acesso em: 17 jul. 2017. 
evolução e as atividades destas ligas brasileiras por meio de seu semanário La Pensée, dirigido por seu secretário, o livre-pensador e maçom belga Eugène Hins (1839-1923).53

Desde o século XVIII, já existia na Alemanha certa tradição filosófica que pugnava para que o Estado garantisse "a liberdade de pensamento e de consciência”, assim como mantivesse "a tolerância religiosa”. Entretanto, possivelmente por sua tradição protestante, a "Aufklärung (Ilustração) alemã não se opôs à verdade religiosa, mas procurou racionalizá-la”. Por conseguinte, a racionalização do religioso contribuiu para uma crítica às religiões históricas, assim como ao "transcendentismo, às superstições, ao particularismo e à dependência da religião da política"54. Portanto, a defesa da liberdade de consciência, racionalização do religioso e independência da Igreja em relação ao Estado estão presentes na cultura filosófica e política alemã desde muito antes do pontificado de Pio IX.

Por sua vez, as "novidades" do Papa Giovanni Ferretti entraram em rota de colisão com esta tradição. A recepção do dogma da infalibilidade papal na Alemanha gerou, como alhures, enorme controvérsia. O resultado último dos conflitos foi a criação de uma nova igreja, a Igreja dos Velhos Católicos, cuja principal liderança teórica e prática esteve sobre os ombros de Johann Joseph Ignaz von Döllinger (1799-1890), teólogo, sacerdote e historiador alemão.

Durante o Concílio Vaticano I, Döllinger entra em uma decidida oposição contra as pretensões de Roma, período em que publica uma série de panfletos e artigos contra o projeto da infalibilidade. $\mathrm{O}$ historiador português António Leitão de Figueiredo - em estudo em que analisa a correspondência de Alexandre Herculano com Döllinger escreve o seguinte sobre os escritos do teólogo alemão: "O principal argumento de todos esses panfletos é que as decisões de igreja em

53 CASANO, Nicoletta. Os vínculos entre os mundos maçônicos e laicos da Bélgica e do Brasil. In: STOLS, Eddy; MASCARO, Luciana Pelaes; BUENO, Clodoaldo (org.). Brasile Bélgica: cinco séculos de conexões e interações. São Paulo: Narrativa Um, 2014. p. 185-186.

54 CATROGA, op. cit., p. 257. 
matéria de dogma têm que ser fundadas na tradição e esta condena toda e qualquer inovação". Figueiredo também escreve que "o dogma da infalibilidade viria, pois, obrigar a cristandade a acreditar de hoje em diante em uma coisa que a Igreja nunca até agora ensinou nem acreditou"55.

Como não se submeteu aos novos dogmas da Santa Sé, em 18 de abril de 1871 Döllinger foi publicamente excomungado de sua posição de padre. Sintomaticamente, ao ser "desligado" da Igreja Católica, foi imediatamente acolhido pelo mundo acadêmico, pois a "Academia de Ciências de Viena nomeou-o seu sócio em 1870, a de Marburgo em abril do ano seguinte. Em 1872 é eleito reitor da sua Universidade, a 15 de maio do ano seguinte Presidente da Academia das Ciências da Baviera"56. O movimento dos velhos católicos não se esfriou face às investidas da Igreja Católica. Pelo contrário, fortaleceu-se com Bismarck, que "desencadeou uma vasta campanha contra a Igreja Católica com vista a excluí-la da vida política alemã. O Kulturkampf (1871-88) "tinha por objetivo submeter sob este ponto de vista a Igreja Católica às autoridades estatais, subtraindo o funcionamento da Igreja à obediência romana"57.

Ora, as medidas de Bismarck não refletiram apenas em França, mas ecoaram fortemente no Brasil. O deputado ultramontano Tarquínio de Souza, em discurso que avalia a gravidade da questão dos bispos, afirma: "A questão religiosa é hoje no mundo, por toda parte, a mais grave de todas as questões (apoiados); é aquela que resume e domina todas as outras (apoiados)". Ainda segundo o deputado, em diversos países estavam ocorrendo tensões e conflitos entre os dois poderes, contudo, "nenhum deles havia ousado interferir na esfera de soberania do poder espiritual" e apenas em um caso isso estava acontecendo: na Prússia, de Bismarck. Tarquínio de Souza discursa:

55 FIGUEIREDO, António Leitão de. Herculano e Döllinger: contribuição para o estudo das relações literárias luso-alemãs. Coimbra: Instituto Alemão da Universidade de Coimbra, 1938. p. 10-11.

56 Ibidem, p. 12.

57 GEREMEK, op. cit., p. 211. 
“a questão religiosa que se discute entre nós é, Sr. Presidente, quase a mesma que atualmente se agita na Alemanha, pondo em luta todos os espíritos daquela região". A essa altura, em aparte, o deputado Gusmão Lobo fala: "Não me diga que o governo do Brasil segue a mesma política de Bismarck". A resposta do deputado Tarquínio de Souza é esclarecedora: "Parece-me até que nela se inspira”. Afirma ainda que o governo brasileiro, em suas medidas opressoras da Igreja foi além do governo da Prússia, pois "ali ao menos havia um vislumbre de legalidade”. Entre diversos apartes, o deputado Diogo de Vasconcellos afirmou que o governo brasileiro foi um "Bismarck em caricatura" ${ }^{58}$.

Os argumentos de Döllinger, de que o pontificado de Pio IX estava inovando em matéria de dogma e de que as decisões do Concílio Vaticano I eram inválidas, serão amplamente utilizados no Brasil, tanto por influência dos escritos do próprio Döllinger quanto pelos de Alexandre Herculano. Saldanha Marinho e Rui Barbosa foram os principais divulgadores das ideias de Döllinger no Brasil. O mais conhecido livro do teólogo alemão, a obra O papa e o concílio, foi traduzido e publicado, a pedido de Saldanha Marinho, por Rui Barbosa, em 1877, e tornou-se uma referência para muitos anticlericais no Parlamento. Barbosa, em sua tradução, inseriu uma introdução à obra que era tão extensa quanto o próprio livro do alemão.

Portanto, os casos aqui citados, entre tantos outros, mostram que havia um conhecimento, por parte dos parlamentares brasileiros, do que estava ocorrendo na Europa no que tange à questão religiosa. A militância anticlerical, assim como a clerical, estava em sintonia fina com os debates europeus.

Com relação ao anticlericalismo na França, Jacqueline Lalouette escreve que as primeiras associações de livres-pensadores apareceram durante a Segunda República, apesar de terem uma "existence brève" 59 . Realmente, foi na Bélgica que as associações de livre-pensamento se desenvolveram, associadas sobretudo à promoção dos

58 ACD, Sessão de 11 de junho de 1874, p. 124-129.

59 LALOUETTE, Jacqueline. La libre pensée en France, 1848-1940. Paris: Albin Michel, 1997. p. 29. 
enterramentos civis. Contudo, "l'effondrement du Second Empire conféra une vive impulsion à la Libre Pensée organisée" ${ }^{60}$. Consequentemente, o movimento retorna com força na França no início dos anos 1860, atingindo o seu pleno desenvolvimento no período entre a Terceira República e a Primeira Guerra Mundial. Por mais de três décadas, o livre-pensamento de diversos matizes vicejou na França, tanto em escala local como nacional.

A exemplo do caso belga, no movimento livre-pensador francês surgirão duas tendências: la libre pensée déiste et spiritualiste e la libre pensée athée et matérialiste. A primeira buscava compatibilizar o espiritualismo e o deísmo antidogmático com o anticlericalismo; a segunda, mais radical, defendia uma posição laicista, materialista e ateísta. A primeira praticava um anticlericalismo de inspiração mais republicana; a segunda defendia ideias mais materialistas, forte nos setores de inspiração socialista e anarquista ${ }^{61}$.

O fortalecimento do livre-pensamento na França coincide com a guinada conservadora do pontificado de Pio IX. Por isso, não surpreende que Jacqueline Lalouette, em outro trabalho, tenha como recorte cronológico inicial exatamente a década de 1870: "En lo esencial, que prevaleció durante esos decenios fue la oposición entre una Iglesia anclada en posiciones clericales y una República que multiplicaba las ofensivas anticlericales" ${ }^{2}$. Com efeito, o movimento anticlerical teve um crescimento exponencial durante a Terceira República francesa. Fernando Catroga elucida essa afirmativa, citando alguns números sintomáticos da força do movimento naquele país: “em 1884, 207 sociedades fizeram-se representar num congresso anticlerical, realizado em Lyon; e, entre 1889 e 1894 estavam instaladas 590 associações de inspiração anticlerical"63.

60 Ibidem, p. 39.

61 Ibidem, p. 143-161.

62 LALOUETTE, Jacqueline. El anticlericalismo en Francia, 1877-1914. Ayer, Madrid, n. 27, p. 15-38, 1997. p. 16.

63 CATROGA, op. cit., p. 262. 
Em França, os republicanos, no poder desde 1870, consolidam a sua influência com as eleições de 1875, em que obtêm a maioria. Em 1881, as eleições dão um esmagador triunfo aos republicanos, que controlam agora toda a vida política, rural e urbana. As medidas do Ministro da Educação da Terceira República, Jules Ferry, tinham como objetivo imediato secularizar a vida pública, começando em seu lugar-chave: a escola. Desencadeia-se então uma luta contra as ordens religiosas e sua influência no ensino, culminando com a expulsão dos jesuítas e doutras congregações, e reforçada em $1882 \mathrm{com}$ a supressão dos emolumentos aos religiosos ${ }^{64}$.

Antes dessas medidas, os republicanos já haviam definido com clareza o inimigo. Em 4 de maio de 1877, Leon Gambetta pronunciou na Câmara dos Deputados as palavras que serão repetidas à profusão: "le cléricalisme, uoilá l'ennemi". Lalouette reconstrói o ambiente político em que estas palavras foram proferidas, e isso serve para evidenciar o grau de tensão que havia no Parlamento francês e na própria sociedade entre anticlericais e clericais:

El discurso de Gambetta se inscribía en un debate provocado por una interpelación de Leblond, miembro de la izquierda republicana, quien pretendía denunciar los "manejos ultramontanos", es decir, las peticiones católicas y las cartas pastorales de algunos bispos - los de Nevers, Vannes o Nimes - relativas a la situación del Papa. El mismo 4 de mayo, el Gobierno tuvo que aceptar una orden del día, votada por 346 diputados, que presentaba "las manifestaciones ultramontanas" como "una violación flagrante de las leyes del Estado" [...], una "agitación antipatriótica". Tres días después, Émile de Girardin proponía el siguiente diagnóstico, muy pertinente: "(La votación del 4 de mayo) ha distribuido la Cámara de diputados en dos campos: en uno, todos los enemigos de la forma electiva y de la libertad religiosa; en el otro, todos los enemigos de la herencia dinástica y del clericalismo". En menos de quince días estalló la crisis del 16 de mayo, cuya verdadera causa fue, sin lugar a dudas, la cuestión del clericalismo y de su hermano enemigo, el anticlericalismo. La jerarquía eclesiástica y el clero, tanto el secular como el regular, se emplearon a fondo en la lucha [...]. Hasta

64 MARTINS, op. cit., p. 66. 
la Unión Sagrada, los altercados entre esos gemelos irreconciliables llamados "clericalismo" y "anticlericalismo" pesaron con fuerza en la política francesa. ${ }^{65}$

A historiadora ressalta ainda que a militância anticlerical na França foi de uma intensidade impressionante, e que a Lei de Separação de 1905 foi o culminar de um longo processo de luta pela secularização:

Incluso con anterioridad a la Ley de Separación de las Iglesias y el Estado de 9 de diciembre de 1905, los republicanos establecieron toda una serie de separaciones dirigidas a afianzar la preeminencia absoluta del Estado y la libertad de conciencia de todos los ciudadanos. "La separación de la Iglesia y de la escuela”, por retomar la expresión de Pierre Chevallier, fue garantizada por la célebre Ley de 28 de marzo de 1882, pronto completada por la Ley de 30 de octubre de 1886, llamada Ley Goblet, menos conocida pero igualmente importante, que hacía obligatoria la laicización del personal docente de las escuelas primarias públicas. ${ }^{66}$

O exemplo da França era recorrentemente utilizado no Parlamento brasileiro, como se pode verificar no discurso do deputado Pinheiro Guimarães em que apela para que no Brasil, ainda que haja união entre Igreja e Estado, decrete-se a plena liberdade de culto, como na França da Terceira República: "O que exijo somente, em nome das luzes do século, dos direitos do homem, dos interesses do país, é que as premissas constitucionais tenham pleno desenvolvimento". Então conclui: "que aqui, como na França cristianíssima, qualquer cidadão, sejam quais forem as suas crenças religiosas, possa subir as mais elevadas posições do país; que um Guizot, apesar de protestante, possa ser ministro de Estado" ${ }^{67}$ (grifo nosso).

65 LALOUETTE, op. cit., p. 20.

66 Ibidem, p. 20-21.

67 ACD, Sessão de 30 de maio de 1873, p. 225-226. 
Sucintamente analisados, os três países foram os mais recorrentemente citados no Parlamento brasileiro no século XIX quanto ao tema do anticlericalismo. Em discurso no Senado, Visconde de Souza Franco afirma que as encíclicas de Pio IX e o Syllabus eram nocivos à nação, visto que a Igreja determinava "no Syllabus que o católico apostólico romano desobedeça a soberania nacional, abomine os progressos do século e as liberdades modernas". Para o senador, essa prática da Igreja não se limitava apenas ao Brasil, pois "na França, na Bélgica, na Alemanha e em outros países passa como princípio incontestável que não pode ser liberal e querer o progresso do país aquele que entende dever obediência à voz de uma autoridade externa" ${ }^{\prime 68}$.

Com relação ao fenômeno do anticlericalismo em Portugal, Luís Machado de Abreu afirma que existem três aspectos consensuais sobre o tema:

Em primeiro lugar, os afloramentos da atitude anticlerical existem desde sempre na tradição cultural portuguesa. Desde as cantigas medievais até aos recentes assomos de incomodidade causadas pelas convicções católicas de um Primeiro Ministro socialista num Estado laico. Depois, essas manifestações apresentam-se com notória publicidade literária, mesmo nos casos em que nela se reflectem iniciativas ou decisões de índole política, social ou educativa. Finalmente, o apogeu da visibilidade expressiva e sintomática do fenômeno anticlerical corresponde ao período compreendido entre meados do século XIX e as duas primeiras décadas do século XX. ${ }^{69}$

Como se vê, o apogeu do anticlericalismo em Portugal, assim como no Brasil, foi dinamizado, externamente, pelo pontificado de Pio IX.

É certo que antes do anticlericalismo de cariz livre-pensador mais radical e abraçado por positivistas e republicanos - existiu em Portugal o anticlericalismo liberal. Vítor Neto escreve que "os grupos

68 ASI, Sessão de 1 de julho de 1874, v. I, p. 7-13.

69 ABREU, op. cit., p. 35. 
sociopolíticos que realizaram as reformas eclesiásticas na fase inicial do liberalismo eram, em geral, portadores de um sentimento e de uma ideologia anticlericais". No entanto, esses anticlericais liberais do início do século XIX eram, na sua maioria, deístas, pois "aceitavam o catolicismo e viam na religião um instrumento de sociabilidade e de unificação das consciências, embora atribuíssem características fundamentalmente profanas ao poder político"70.

Fernando Catroga ressalta que "a vertente livre-pensadora do anticlericalismo" em Portugal manifestou-se um pouco mais tardiamente, "embora tenha alcançado uma radicalidade só explicável pela dimensão vanguardista (e minoritária) que ganhou” e em razão do forte clericalismo e sua resistência à modernidade. Em Portugal, somente na década de 1870 se encontram atitudes e grupos influenciados pelos movimentos belgas e franceses ${ }^{71}$.

Os livres-pensadores da década de 1870 reatualizaram uma série de ações anticlericais que remontavam aos séculos XVI, XVII e XVIII - em especial o antijesuitismo e o anticongreganismo - para a nova realidade. "Por sua vez, a evolução doutrinal do Papado, não só dava atualidade ao antijesuitismo e ao anticongregacionismo, como exigia novas respostas filosóficas, novas formas de luta e objetivos mais alargados"72. As novas formas de militância, com a dilatação dos objetivos dos anticlericais, podem ser percebidas em função da fundação de diversos jornais e de associações.

No contexto do "alargamento do caderno reivindicativo do anticlericalismo português" - propugnava-se uma secularização externa da sociedade e interna das consciências. A luta pela regulamentação e propagação do registro civil foi o elemento que organizou o livre-pensamento em Portugal. Nesse contexto, surge a Associação Promotora do Registro Civil (1876): inspirada no modelo dos livres-pensadores belgas, franceses e espanhóis. Foram desencadeadas várias campa-

70 NETO, op. cit., p. 323.

71 CATROGA, op. cit., p. 272.

72 Ibidem, p. 273. 
nhas contra o clero que buscavam quebrar "o monopólio que a Igreja detinha sobre os ritos de passagens", retirando do clero o controle da vida civil: registro de nascimento, casamento e óbitos ${ }^{73}$.

Fernando Catroga também escreve que, assim como os liberais do início do século XIX, o renovado movimento anticlerical português não punha em causa a existência de um Deus criador.

Isto é, criticavam o clero - devido a sua submissão a uma autoridade estrangeira, a sua ignorância, ao seu reacionarismo político e a sua ameaça à harmonia e privacidade dos lares (como consequência do celibato e da confissão) - mas defendiam a necessidade espontânea de se acreditar em Deus e viam no cristianismo a expressão suprema dessa crença e, no próprio catolicismo - desde que liberalizado - a tradução ritual e simbólica mais adequada à vida em sociedade. ${ }^{74}$

Mesmo na sua versão mais radical, continuavam sendo anticlericais, não anticatólicos.

Finalmente, os anticlericais socialistas, além de incorporar o repertório anticlerical dos liberais e republicanos, ligaram mais estreitamente a questão social com a questão religiosa, alargando ainda mais os seus horizontes e objetivos. Visavam destruir a base sociopolítica, cultural e mental que daria força ao catolicismo, enfim, anelavam uma transformação global da sociedade. O fundo ateísta já não era escamoteado. Para os socialistas, "o clero seria a face visível do verdadeiro inimigo: a ideia de Deus”. Entendiam que o único caminho de uma sociedade verdadeiramente justa era a aplicação do princípio nem Deus, nem padres. Catroga escreve que para o anticlerical de cariz socialista "não bastava repetir o slogan, proferido por Gambetta em 4 de maio de 1877: 'o clericalismo, eis aí o inimigo', porque já não traduzia 'a verdade inteira: A religião, eis aí o inimigo, é que deve ser o brado de todos os livres-pensadores"'75. Os socialistas foram particularmen-

73 Ibidem, p. 276, 279, 285.

74 Ibidem, p. 275.

75 Ibidem, p. 296. 
te ativos em fins do século XIX, pois, conforme escreve Vítor Neto, "promoveram a realização de romagens ao túmulo de Sara de Matos, fundaram os círios civis (1894), realizaram os Congressos Socialistas Anticlericais de 1895 e de 1900 e restabeleceram a Associação Promotora do Registro Civil (1895)"76.

Portanto, no final do século XIX e início do XX, "verifica-se que os ataques a Igreja, feitos pelos livres-pensadores, apareciam cada vez mais acompanhados pela crítica aos fundamentos da própria religião". Também se invocava para isso a ciência, a razão filosófica, argumentos históricos e sociológicos para defender a "falsidade do próprio conceito de Deus”. Reforçava-se a certeza (tida como científica) segundo a qual a desalienação religiosa só seria possível se, concomitantemente, se concretizasse a emancipação social e política dos oprimidos. Passou-se a externalizar que os valores religiosos dominantes eram mentiras ${ }^{77}$.

$\mathrm{O}$ anticlericalismo em Portugal não teve fim nem mesmo com o advento da República (1910), que promulgou a Lei de Separação entre Igreja e Estado (20 de abril de 1911). Pois, conforme analisa Maria Lúcia de Brito Moura, a República, através de sua legislação radicalmente secularizadora, longe de pacificar as relações entre o Estado e a Igreja, cooperou - ao lado também da intransigência do próprio clero - para um conflito que se arrastou por quase uma década: “O 5 de Outubro é, assim, um 'ponto de chegada', constituindo igualmente um ponto de partida para uma nova realidade, onde a 'guerra religiosa' conhecerá embates muito mais violentos que no passado"78.

As fontes utilizadas sinalizaram que o caso do anticlericalismo português, apesar de apresentar muitas semelhanças com a experiência brasileira, sobretudo no seu cariz livre-pensador, pouca ou quase nenhuma repercussão teve no Parlamento no século XIX. Em discurso no Senado Imperial, Silveira da Motta afirmou que a decla-

76 NETO, op. cit., p. 341.

77 CATROGA, Op. Cit., p. 299-300.

78 MOURA, Maria Lúcia de Brito. A "guerra religiosa” na I República. 2. ed. Lisboa: CEHR-UCP, 2010. 
ração de dogmatização da infalibilidade papal pelo Concílio Vaticano I trouxe diversas consequências em muitos países. O parlamentar ressalta que tal declaração dividiu a Igreja na Alemanha, dando origem ao movimento dos velhos católicos, bem como gerou problemas análogos na Áustria, Baviera, Suíça e Espanha, afetando o Brasil. A certa altura do discurso, em aparte, um senador não identificado pergunta: "E Portugal?”. Então Silveira da Motta fornece uma resposta reveladora: "O pequeno Portugal (que pouca influência exerce nestas questões grandes), esse mesmo está com o seu direito de padroado ${ }^{79}$; é o país mais regalista que há (apoiados)"\$0. Com efeito, nos debates parlamentares, raríssimas foram as vezes que Portugal foi mencionado. Deliberadamente ou não, o fato é que a luta dos anticlericais, livres-pensadores e socialistas portugueses não foi chamada à colação para fundamentar os discursos dos parlamentares anticlericais no Brasil Imperial.

No processo de separação entre o Estado e a Igreja em Portugal, o exemplo brasileiro foi cotejado. Em 27 de junho de 1911, na $7^{\text {a }}$ Sessão da Assembleia Nacional Constituinte do Estado Português, o deputado Eduardo Abreu, antigo emigrante do Brasil, questionou o Governo Provisório daquele país sobre alguns aspectos da Lei de Separação da Igreja do Estado (1911). Ao fazer isso, o deputado apresentou di-

79 "Padroado" era uma instituição de origem medieval pela qual a Igreja Católica atribuía a certos indivíduos ou instituição - nomeadamente na Península Ibérica -, a condição de padroeiro de certo território para "a manutenção e propagação da fé cristã". Nessa relação, o padroeiro auferia alguns privilégios, como a "coleta dos dízimos e a prerrogativa de indicar religiosos para o exercício de funções religiosas". Os reis de Portugal, na sequência das lutas contra os "infiéis" mouros, receberam diversos direitos e deveres de padroeiros (outorgados por Leão X em 1514, e por Júlio II em 1550), que, além dos já mencionados, os habilitava a propor a criação de novas dioceses, assim como o do "beneplácito", isto é, a prerrogativa que os monarcas possuíam de aprovar (ou não) as determinações, bulas, breves da "Santa Sé que se destinassem ao reino". Como esses direitos foram concedidos à casa portuguesa de Avis, e mais tarde à casa de Bragança, os imperadores brasileiros, como herdeiros diretos desta, exigiram e assumiram unilateralmente o padroado sobre a Igreja brasileira. Tal postura regalista foi consolidada na Constituição outorgada de 1824. Cf. NEVES, Guilherme Pereira das. Padroado. In: VAINFAS, Ronaldo (org.). Dicionário do Brasil Colonial (1500-1808). Rio de Janeiro: Objetiva, 2001. p. 465-466.

80 ASI, Sessão de 17 de maio de 1873, tomo I, p. 381. 
versos exemplos históricos sobre modelos de relações entre Estado e Igreja na Europa e na América, detendo-se no caso brasileiro, inclusive citando literalmente todo o Decreto 119-A. O deputado considerou esse documento como "uma clamorosa lição de patriotismo, de bom senso, de nobreza, de sabedoria e de equidade"s1. A lei brasileira de separação entre a Igreja e o Estado precedeu a portuguesa em 21 anos. A ex-colônia estava dando "lições" a sua ex-metrópole.

\section{EUA: um modelo a que "todos recorrem"}

A documentação e a bibliografia utilizadas na redação deste trabalho deixou claro que os deputados e senadores brasileiros estavam informados sobre os movimentos dos livres-pensadores, anticlericais e católicos liberais em alguns países europeus, nomeadamente Bélgica, Alemanha e França. Entretanto, os distanciamentos da trajetória histórica e política do Brasil em relação aos países mencionados limitavam o potencial comparativo com a realidade brasileira. $\mathrm{O}$ mesmo não acontecia com os Estados Unidos, que, como o Brasil, tinha sido colônia e emancipara-se, tornando-se uma União independente e em crescimento galopante. Com efeito, a maioria dos defensores da tese da separabilidade viam-se no modelo norte-americano consubstanciado na I Emenda Constitucional (1791). O próprio deputado ultramontano Tarquínio de Souza asseverou, sem nenhuma contestação, que os Estados Unidos eram "o país ao qual recorrem todos para demonstrar a tese da separação da Igreja do Estado"s2.

É possível afirmar que o movimento anticlerical nos países de tradição protestante ocorreu no contexto das reformas religiosas dos séculos XVI e XVII. Efetuou-se, nessa época, o processo de desclericalização da sociedade, assim como a ruptura com Roma. No caso dos Estados Unidos, desde a sua fundação como nação, foi criado o

81 ABREU, Eduardo. Discurso na $7^{\mathrm{a}}$ Sessão, em 27 de junho de 1911. In: PORTUGAL. Diário da Assembleia Nacional Constituinte. Lisboa, 1911. Disponível em: https://bit.ly/2Fw5Ess. Acesso em: 11 fev. 2018.

82 ACD, Sessão de 30 de maio de 1873, p. 223. 
chamado "muro de separação" entre a Igreja e o Estado. Ora, a lógica que explica este processo é bem diferente da lógica francesa. $\mathrm{Na}$ França, o livre-pensamento e o anticlericalismo refletiam a forte hostilidade do Estado para com a religião católica, sobretudo em função de esta Igreja estar identificada com o Antigo Regime. Nos Estados Unidos, foram as próprias igrejas que apoiaram a plena autonomia em relação ao Estado, como meio de proteção contra as intervenções do governo, consideradas excessivas em matéria religiosa. Portanto, no século XIX, os conflitos entre o poder temporal e o espiritual, que tantos problemas causavam nos países católicos, estavam praticamente ausentes nos Estados Unidos e nas demais nações protestantes. Ora, como esses países não enfrentaram o problema do clericalismo, o seu irmão siamês, o anticlericalismo, também ficou adormecido.

Para Horst Mewes, "o princípio teórico da 'separação' não foi inventado pelos revolucionários americanos" no contexto da Independência. É-lhes anterior. Por exemplo, em 1689, John Locke, geralmente considerado a principal fonte da proclamação americana dos direitos naturais, já era a favor de uma separação rigorosa entre a "proteção da vida e dos bens" e a "salvação da alma". Na sua Carta sobre a tolerância, Locke insistia na necessidade de "distinguir com precisão as funções do governo civil das da religião e definir os limites entre uma e outra" ${ }^{33}$. Na realidade, o princípio da separação é anterior ao próprio John Locke. Em sua maioria, os "pais peregrinos" puritanos que fundaram as primeiras colônias norte-americanas, eram calvinistas. Por conseguinte, os escritos de João Calvino certamente não eram desconhecidos dos alfabetizados colonizadores. Em sua mais conhecida obra, A instituição da religião cristã ${ }^{84}$, Calvino deixa evidente a necessidade de separar o poder temporal e o espiritual:

83 MEWES, Horst. Reflexões sobre religião e política na democracia americana. In: MESQUITA, Mário; VICENTE, Paula; ZAGALO E MELO, Paulo. Repúblicas em paralelo: Portugal - Estados Unidos da América. Lisboa: Fundação Luso-Americana, 2010. p. 47.

84 A primeira edição de $A$ instituição da religião cristã, ou Institutas, como também é identificada, foi publicada em 1536 e não chegava a ter 200 páginas. A última edição veio a lume em 1559 e já contava com quase 1.200 páginas. No Brasil, existem duas grandes traduções, uma pela editora 
Em primeiro lugar, antes de prosseguir neste assunto, devemos nos deter rapidamente na distinção que fizemos antes. Caso contrário, seremos levados a uma confusão imprudente entre as duas coisas que distinguimos, as quais são de natureza totalmente diversa. [...] Mas qualquer um que saiba como distinguir entre a alma e o corpo, entre esta vida transitória atual e a vida eterna que está por vir, não terá dificuldade em compreender que o reino espiritual de Cristo e o governo civil são coisas muitíssimo distantes uma da outra ${ }^{85}$ (grifo nosso).

Tendo como influência a tradição calvinista e os princípios estabelecidos por John Locke, Thomas Jefferson desenvolve no texto $A$ bill for establishing religious freedom, de 1786, as bases do princípio geral de que "a religião está totalmente isenta da necessidade de reconhecimento por parte da sociedade civil". Um ano antes, James Madison, em sua declaração intitulada Memorial and remonstrance against religious assessments, resumiu os principais argumentos em favor da separação entre o governo e as igrejas: antes de terem quaisquer "obrigações em relação às pretensões da sociedade civil", os homens devem considerar-se "sujeitos ao Governador do Universo"; pois, segundo esse Governador, "a liberdade de consciência está no cerne da fé religiosa e é um direito inalienável do homem”; por fim, “a fé cristã é suficientemente forte para florescer por si sem necessidade do apoio de leis civis humanas"

Entretanto, para Mewes, uma das principais lições da experiência histórica americana é que a separação entre Igreja e Estado não resultou na separação entre as confissões religiosas e a ação política. Pelo contrário, a livre prática da religião deu origem a uma proliferação sem precedentes de confissões religiosas que passaram a exercer suas "convicções religiosas seja na sociedade seja na política" ${ }^{87}$. Em

Cultura Cristã e outra pela editora Unesp. A edição utilizada aqui está inserida na obra de HÖPFT, Harro (org.). Lutero e Calvino: sobre a autoridade secular. 2. ed. São Paulo: Martins Fontes, 2005. (Clássicos Cambridge de Filosofia Política).

85 CALVINO, João. Sobre o governo civil. In: HÖPFT, op. cit., p. 73-74.

86 MEWES, op. cit., p. 48.

87 Ibidem, p. 49. 
função dessa realidade, muitos estudiosos consideram que a democracia americana difere significativamente das europeias no que respeita à importância da religião, tanto na vida da sociedade como na ação do governo ${ }^{88}$. Mewes escreve: "Diz-se que, nos Estados Unidos, o público em geral é mais religioso e não hesita em adquirir influência política para fins inspirados pela religião". Esta diferença notória tem sido associada à noção do "excepcionalismo americano" 89.

Com relação à presença do modelo dos Estados Unidos no Brasil imperial, sua maior influência sobre o Parlamento brasileiro está associada, como é lógico, à questão da separação entre Igreja e Estado. Naturalmente, as apreciações sobre o exemplo norte-americano nas casas parlamentares eram diversas. Sobre o tópico da separação, afirma Tarquínio de Souza que "esta nação não pode servir de base à argumentação que dele se quer tirar", uma vez que "entre nós, segundo as circunstâncias peculiares em que nos achamos, esta separação é de todo o ponto impossível"9o.

Tinha a mesma opinião o famoso literato e deputado conservador José de Alencar, que, apesar de esboçar um anticlericalismo de tipo liberal, colocava-se contra a separação entre Igreja e Estado, que considerava um ateísmo nacional. Em suas objeções ao princípio da separabilidade, Alencar afirmava que os conflitos decorrentes da união entre os poderes não causavam tanto mal como aquele "que produziria a permanência de uma sociedade sem os vínculos da religião, sobre a qual repousa a amoralidade pública". Para corroborar a tese de que o Estado necessita de um fundamento religioso, citava Gladstone, figura "que deve ter grande autoridade para o partido liberal", e

88 CATROGA, Fernando. Entre deuses e césares: secularização, laicidade e religião civil. Coimbra: Almedina, 2006. p. 436-445.

89 Horst Mewes ressalta que "a noção de excepcionalismo americano não se refere apenas ao papel da religião na democracia americana. Tem sido afirmado que a América é uma excepção a vários outros fenômenos modernos que caracterizam a história europeia, tal como a ascensão dos partidos socialistas e trabalhistas e dos movimentos fascistas". MEWES, op. cit., p. 43.

$90 \mathrm{ACD}, 30$ de maio de 1873, p. 216-223. 
para quem "o fim principal da sociedade é a propagação da religião"91. Contra os que recorriam ao modelo norte-americano, afirmava que os Estados Unidos ainda eram uma nação jovem e não tinham sido testados em sua diversidade religiosa. "Não há nos Estados Unidos uma verdadeira religião: há seitas unicamente, que hão de produzir em breve a anarquia religiosa", porque lhes falta "a homogeneidade e a coesão" 92 .

Não há dúvidas que, para os defensores da separação entre Igreja e Estado, o "modelo" da América do Norte era evocado com certa regularidade. Muitos não hesitavam em associar o progresso americano a sua plena liberdade religiosa. O grande defensor do modelo americano no Senado foi Luiz Vieira da Silva. Segundo ele, "as tendências do século vão-se encaminhando para abraçar-se o sistema da União Norte-Americana, onde o Estado não se importa com religião nenhuma, podendo cada um seguir a que melhor lhe parecer". Por defender essa e outras bandeiras, foi acusado de ser "tão herege como o Souza Franco. Quiseram até chamar-me ateu; mas não há tal"93.

\section{Considerações finais}

Como pôde ser constatado, foi em meados do século XIX que o clericalismo, agora na forma de ultramontanismo, ganhou maior relevância no Brasil e em alguns Estados europeus. Nesse contexto, por meio da encíclica Quanta cura e do Syllabus, o romanismo elencou uma série de inimigos modernos que deveriam a todo custo ser combatidos. Foi o período da ascensão ultramontana.

As ações de Pio IX resultaram na circulação transatlântica de ideias anticlericais. Apesar de não identificarmos uma sistemática articulação entre os anticlericais das duas margens do Atlântico, a realidade foi que, na segunda metade do Oitocentos, as experiências

$91 \mathrm{ACD}$, Sessão de 30 de maio de 1873, p. 189

92 ACD, Sessão de 28 de maio de 1873, p. 188.

93 ASI, Sessão de 15 de junho de 1875, v. II, p. 177-181. 
conflituosas europeias, envolvendo os opositores dos ultramontanos, eram bem conhecidas no Parlamento imperial brasileiro.

A visão panorâmica aqui apresentada nos permite constatar que a experiência do anticlericalismo brasileiro, quando comparada com alguns casos europeus, alcançou certo pioneirismo em relação à separação entre o Estado e a Igreja de Roma. Antecedeu em quinze anos ao clássico modelo da laicité francesa e em 21 anos a lei de separação portuguesa, sem mencionar a proeminência em relação a alguns Estados latino-americanos ${ }^{94}$.

Concordamos que os Estados Unidos foram o modelo para muitas das decisões que o governo republicano brasileiro adotou, incluindo o relacionamento entre o Estado e a Igreja. No entanto, deve-se lembrar que a separação à americana implicou uma emenda constitucional (1791) e que ela ocorreu num clima de relativo consenso entre as igrejas dominantes (boa parte delas de tradição calvinista) e um novo poder político que, em simultâneo, fundava uma nação. Por outras palavras, nos EUA foram as igrejas protestantes, criadas por imigrantes que haviam vivenciado a experiência das guerras religiosas na Europa, que desejaram a separação. Ora, nos países católicos, o

94 Quando comparado com alguns países da América Latina (entre eles pode-se citar Argentina, Bolívia e Costa Rica), com Portugal e, fundamentalmente, com a França, modelo paradigmático de luta pela laicidade do Estado, o Brasil ocupa certa posição de vanguarda na separação do Estado da Igreja Católica. Em que pese o que se afirmou acima, vale mencionar que Colômbia, México, Guatemala e Honduras implantaram o regime de separação entre Igreja e Estado repectivamente em 1853, 1859, 1879 e 1880. Ari Pedro Oro e Marcela Ureta analisaram a constituição de vinte países na América Latina, privilegiando aqueles que foram fruto de uma colonização ibérica. Acerca das relações entre Estado e Igreja hoje, os autores afirmam que existem três distintos posicionamentos: aqueles que adotam o regime de Igreja de Estado (Argentina, Bolívia e Costa Rica); os que adotam o regime de separação Igreja e Estado, com dispositivos particulares em relação à Igreja Católica (Guatemala, El Salvador, Panamá, Republica Dominicana, Peru e Paraguai); e, enfim, aqueles que mantêm um regime de separação Estado-Igreja com a consequente igualdade de cultos (México, Haiti, Honduras, Nicarágua, Cuba, Colômbia, Venezuela, Equador, Brasil, Chile e Uruguai), evidenciando os diversos posicionamentos até a atualidade. Cf. ORO, Ari Pedro; URETA, Marcela. Religião e política na América Latina: uma análise da legislação dos países. Horizontes Antropológicos, Porto Alegre, v. 13, n. 27, p. 281-310, 2007. Disponível em: https:// bit.ly/3052OfE. Acesso em: 6 jan. 2017. 
processo foi diferente, porque a separação ocorreu em Estados-nação já implantados e deu-se em confronto com a hegemonia de uma estrutura eclesiástica pouco atenta aos processos de nacionalização e de modernidade. Por isso, a separabilidade emergiu, regra geral, em contexto de confronto entre duas atitudes estruturais, designadas a partir de meados do século XIX por clericalismo e anticlericalismo, realidade quase inexistente na cultura política e ideológica dos países de maioria protestante.

Daqui inferimos outra conclusão: reduzir a compreensão da separabilidade à comparação exclusiva com o seu modelo americano será reduzir o processo à letra da Lei de Separação ${ }^{95}$. Portanto, o caso da separabilidade à brasileira deve mobilizar diversas tradições: a americana, a alemã e a franco-belga. No caso brasileiro, houve sempre uma resistência da Igreja institucionalizada à desconfessionalização do Estado, realidade que não esteve presente nos Estados Unidos.

Em suma: o fato de o "modelo" americano ter sido evocado por alguns dos parlamentares que defendiam a tese da separabilidade no Brasil, não invalida a necessidade de sustentar esta outra faceta da questão. Com efeito, o debate estava sendo esgrimido num país católico, onde, ao contrário do que aconteceu com as igrejas protestantes dos EUA, a Igreja oficial resistia a tudo o que pudesse alterar sua condição ou soasse à secularização da sociedade e do Estado. Concomitantemente, as personalidades e movimentos que, no Brasil, a defenderam, conquanto em nome da liberdade de consciência, como os seus êmulos norte-americanos, partiam desse pano de fundo resistente, sinal de que só uma vitória política sobre essa "hostilidade", por mais hábil e tática que fossem as suas manifestações, levaria à separação. Daí que, ao contrário do que aconteceu nos EUA, no Brasil, como em outros países católicos da América e da Europa, o debate sobre a secularização (e laicização) do Estado irrompeu umbilical-

95 Encontramos o manuscrito do Decreto 119-A na Fundação Casa Rui Barbosa. Cf. BARBOSA, Rui. Decreto $s / n, 7$ de janeiro de 1890. Estabelece a plena liberdade de cultos e decreta a separação entre a Igreja e o Estado. Setor de manuscrito. Arquivo da Fundação Casa Rui Barbosa. 2 p. 
mente ligado à agenda da luta anticlerical, a qual, no entanto, teve expressões com intensidades diversas.

\section{Fontes}

ABREU, Eduardo. Discurso na $7^{\text {a }}$ Sessao, em 27 de junho de 1911. In: PORTUGAL. Diario da Assembleia Nacional Constituinte. Lisboa, 1911. Disponivel em: https://bit.ly/2Fw5Ess. Acesso em: 11 fev. 2018.

BARBOSA, Rui. Decreto $s / n, 7$ de janeiro de 1890. Estabelece a plena liberdade de cultos e decreta a separacao entre a Igreja e o Estado. Setor de manuscrito. Arquivo da Fundacao Casa Rui Barbosa. 2 p.

BRASIL. Annaes da Camara dos Deputados (ACD). Sessao 27 de julho de 1880, tomo I, Apendice, p. 149. Rio de Janeiro: Typ. Nacional, 1880. Disponivel em: https://bit.ly/351pO6r. Acesso em: 17 jul. 2017.

ACD, Sessao de 30 de maio de 1873.

ACD, Sessao de 30 de maio de 1873.

ACD, Sessao de 11 de junho de 1874.

ACD, Sessao de 28 de maio de 1873.

ACD, Sessao de 30 de maio de 1873.

ACD, Sessao de 30 de maio de 1873.

BRASIL. Annaes do Senado Imperial (ASI). Sessao 1 de julho de 1874, v. I, p. 7-13. Rio de Janeiro: Typ. Nacional. Disponivel em: https:// bit.ly/3k3fiit. Acesso em: 17 jul. 2017.

ASI, Sessao de 15 de junho de 1875, v. II.

ASI, Sessao de 17 de maio de 1873, tomo I.

ASI, Sessao de 27 de junho de 1874, Apendice.

PAPA GREGORIO XVI. Mirari Vos: carta enciclica promulgada em 15 de agosto de 1832, sobre os principais erros de seu tempo. Disponivel em: https://bit.ly/3nU120K. Acesso em: 12 ago. 2016.

PAPA PIO IX. Quanta Cura: carta enciclica promulgada em 8 de dezembro de 1864, sobre os principais erros da epoca. Disponivel em: https://bit. ly/37aMbZK. Acesso em: 25 out. 2015.

PAPA PIO IX. Syllabus: contendo os principais erros da nossa epoca, promulgada em 8 de dezembro de 1864. Disponivel em: https://bit.ly/3nU120K. 
Acesso em: 12 ago. 2016.

\section{Bibliografia}

ABREU, Luis Machado de; MIRANDA, Antonio Jose Ribeiro (org.). O anticlericalismo portugues: historia e discurso: actas do coloquio. Aveiro: Universidade de Aveiro, 2002.

ABREU, Luis Machado de. Ensaios anticlericais. Lisboa: Roma Editora, 2004.

AYER. Madrid: Asociacion de Historia Contemporanea, v. 27, 1997. El anticlericalismo. Edicao de Rafael Cruz Martinez.

BARNADAS, Josep. A Igreja Catolica na America espanhola colonial. In: BETHELL, Leslie (org.). Historia da America Latina: America Latina colonial. Sao Paulo: Edusp, 1998. v. 1. p. 521-551.

BERGER, Peter. Os multiplos altares da modernidade: rumo a um paradigma da religiao numa epoca pluralista. Petropolis: Vozes, 2017.

BRUIT, Hector H. A invencao da America Latina. In: ENCONTRO DA ASSOCIACAO NACIONAL DE PESQUISADORES E PROFESSORES DE HISTORIA DAS AMERICAS, 5., 2002, Belo Horizonte. Anais [...]. Sao Paulo: ANPHLAC, 2002. p. 1-12. Disponivel em: https://bit.ly/3iTkOWo. Acesso em: 14 jul. 2015.

BRUNEAU, Thomas. O catolicismo brasileiro em epoca de transicao. Sao Paulo: Loyola, 1974.

CASANO, Nicoletta. Os vinculos entre os mundos macônicos e laicos da Belgica e do Brasil. In: STOLS, Eddy; MASCARO, Luciana Pelaes; BUENO, Clodoaldo (org.). Brasil e Belgica: cinco seculos de conexoes e interacoes. Sao Paulo: Narrativa Um, 2014.

CASTRO, Zília Osório de. Antecedentes do regalismo pombalino: o Padre José Clemente. In: POLONIA, Amelia. Estudos em homenagem a Joao Francisco Marques. Porto: Faculdade de Letras da Universidade do Porto, 2002. p. 323-331. Disponivel em: https://bit.ly/2Izp2pT. Acesso em: 12 out. 2016.

CATROGA, Fernando. Entre deuses e cesares: secularizacao, laicidade e religiao civil. Coimbra: Almedina, 2006.

CATROGA, Fernando. O livre-pensamento contra a Igreja: a evolucao do anticlericalismo em Portugal (seculos XIX e XX). Revista de Historia das Ideias, Coimbra, v. 22, p. 255-354, 2001. 
CATROGA, Fernando. A militância laica e a descristianizacao da morte em Portugal: 1865-1911. 1988. Tese (Doutorado em Historia Moderna e Contemporânea) - Departamento de Historia da Universidade de Coimbra, Coimbra, 1988. 2 v.

CLARK, Christopher; KAISER, Wolfram. Culture wars: secular-Catholic conflict in nineteenth-century Europe. Cambridge: Cambridge University Press, 2003.

DI STEFANO, Roberto (org.). Pasiones anticlericales: uno recorrido iberoamericano. Bernal: Universidad Nacional de Quilmes, 2013.

FERREIRA, Antonio Matos. Anticlericalismo. In: AZEVEDO, Carlos Moreira (dir.). Dicionario de historia religiosa de Portugal. Lisboa: Circulo de Leitores, 2001. v. A-C.

FIGUEIREDO, Antonio Leitao de. Herculano e Döllinger: contribuicao para o estudo das relacoes literarias luso-alemas. Coimbra: Instituto Alemao da Universidade de Coimbra, 1938.

GEREMEK, Bronislaw. Igreja. In: ENCICLOPEDIA Einaudi: mythos/logos, sagrado/profano. Lisboa: Imprensa Nacional, 1987. v. 12.

HÖPFT, Harro (org.). Lutero e Calvino: sobre a autoridade secular. 2. ed. Sao Paulo: Martins Fontes, 2005. (Classicos Cambridge de Filosofia Politica).

KANT, Immanuel. "Resposta a pergunta: o que e o Iluminismo". In: KANT, Immanuel. Da paz perpetua e outros opusculos. Lisboa: Edicoes 70, 2009.

LALOUETTE, Jacqueline. El anticlericalismo en Francia, 1877-1914. Ayer, Madrid, n. 27, p. 15-38, 1997.

LALOUETTE, Jacqueline. La libre pensee en France, 1848-1940. Paris: Albin Michel, 1997.

LALOUETTE, Jacqueline. La republique anticlericale, XIXe-XXe siècles. Paris: Seuil, 2002.

MACEDO, Ubiratan Borges de. A ideia de liberdade no seculo XIX: o caso brasileiro. Rio de Janeiro: Expressao e Cultura, 1997.

MARTINS, Antonio Manuel. Recepcao em Portugal das enciclicas sobre o liberalismo Mirari Vos, Quanta Cura e Immortale Dei. Lusitania Sacra, Lisboa, v. 2, n. 1, p. 41-80, 1989. Disponivel em: https://bit.ly/2T43ALj. Acesso em: 12 ago. 2016.

MATOS, Henrique Cristiano Jose. Caminhando pela historia da Igreja. Belo 
Horizonte: Lutador, 1995.

MEWES, Horst. Reflexoes sobre religiao e politica na democracia americana. In: MESQUITA, Mario; VICENTE, Paula; ZAGALO E MELO, Paulo. Republicas em paralelo: Portugal - Estados Unidos da America. Lisboa: Fundacao Luso-Americana, 2010.

MOURA, Maria Lucia de Brito. A "guerra religiosa" na I Republica. 2. ed. Lisboa: CEHR-UCP, 2010.

NETO, Vitor. O Estado, a Igreja e a sociedade em Portugal (1832-1911). Lisboa: Imprensa Nacional, 1998.

NEVES, Guilherme Pereira das. Padroado. In: VAINFAS, Ronaldo (org.). Dicionario do Brasil Colonial (1500-1808). Rio de Janeiro: Objetiva, 2001. p. 465-466.

OLIVEIRA, Anderson Jose Machado de; RODRIGUES, Claudia. El anticlericalismo en el Brasil. In: DI STEFANO, Roberto (org.). Pasiones anticlericales: uno recorrido iberoamericano. Bernal: Universidad Nacional de Quilmes, 2013. p. 191-244.

ORO, Ari Pedro; URETA, Marcela. Religiao e politica na America Latina: uma analise da legislacao dos paises. Horizontes Antropologicos, Porto Alegre, v. 13, n. 27, p. 281-310, 2007. Disponivel em: https://bit.ly/3052OfE. Acesso em: 6 jan. 2017.

REMOND, Rene. L'Anticlericalisme en France: de 1815 a nos jours. Paris: Fayard, 1976.

REMOND, Rene. Introducao a historia do nosso tempo. 4. ed. Lisboa: Gradiva, 2011.

RIEGELHAUPT, Joyce Firstenberg. O significado religioso do anticlericalismo popular. Analise Social, Lisboa, v. 18, n. 72-74, p. 1213-1230, 1982.

SAMPAIO, David. O Concilio Vaticano I e o governo portugues (1869-1870). Lusitania Sacra, Lisboa, v. 2, n. 1, p. 11-40, 1989.

SANTIROCCHI, Italo Domingos. Questao de consciencia: os ultramontanos no Brasil e o regalismo do Segundo Reinado (1840-1889). Belo Horizonte: Fino Traco, 2015.

SILVA, Ivo Pereira da. O Anticlericalismo Politico no Parlamento Brasileiro (1868-1892). Tese (Doutorado em Historia Contemporânea), Faculdade de Letras da Universidade de Coimbra - UC, Coimbra, Portugal, 2018.

SOLIS, Yves; SAVARINO, Franco (org.). El anticlericalismo en Europa y Ameri- 
ca Latina: una vision transatlantica. Ciudad de Mexico: Instituto Nacional de Antropologia e Historia, 2011.

VIEIRA, David Gueiros. O problema do direito civil do imigrante e a queda do gabinete de Olinda, 1866. Revista de Informacao Legislativa, Brasilia, DF, v. 11, n. 44, p. 153-160, 1974.

VOLVELLE, Michel. A Revolucao Francesa contra a Igreja: da razao ao ser supremo. Rio de Janeiro: Jorge Zahar, 1989.

Recebido em: 27/09/2019 - Aprovado em: 22/01/2020 